\title{
The Effect of locus of Control and Organizational Commitment on Acceptance of Dysfunctional Audit Behavior Based on the Theory of Planed Behavior
}

\author{
Reza Rostaminia \\ PhD student,Department of Accounting, Kish International Branch, Islamic \\ Azad University, Kish Island, Iran(r.rostaminia@iau-shoushtar.ac.ir) \\ Rezvan Hejazi * \\ Professor of accounting, Department of Accounting, Kish International \\ Branch, Islamic Azad University, Kish Island, Iran(Corresponding author), \\ Hejazi33@gmail.com \\ Ghodratolah Talebnia \\ associate professor,Department of Accounting, Sciense and Research \\ Branch, Islamic Azad University, Tehran,Iran.(gh_talebnia@yahoo.com) \\ Rasol Baradaran Hasanzadeh \\ associate professor,Department of Accounting, Tabriz Branch, Islamic Azad \\ University, Tabriz, Iran(drh313@gmail.com)
}

\begin{abstract}
:
Acceptance of dysfunctional audit behavior is accepting any activity that is against the audit standards. This behavior is a serious problem for professional auditing that can lead to its failure. The purpose of this study was to examine the effect of internal locus of control, external locus of control and organizational commitment to the acceptance of dysfunctional audit behavior Based on the Theory of Planed Behavior. The target population of this study is the auditors of Iranian Association of Certified Public Accountants in the year 2018. The sample was chosen by random sampling method and 310 auditors were selected by using Cochran formula. Data were collected by questionnaire and then they were analyzed by structural equation model with the approach of Partial Least Squares. The Smart PLS software was used for analyzing the data. The results of the analysis showed that the internal locus of control and organizational commitment had the negative effect and the external locus of control had a positive effect on the acceptance of dysfunctional audit behavior. This means that auditors with internal
\end{abstract}


Semiannually journal of Value \& Behavioral Accounting dof $10.52547 /$ aapc.5.10.129

locus of control and organizational commitment, avoid accepting dysfunctional audit behavior and auditors with external locus of control tend to accept the audit dysfunctional behavior.

Keywords: Acceptance of Dysfunctional Audit Behaviors, Locus of Control, Organizational Commitment, Premature sign-off, Theory of Planned Behavior

\section{Copyrights c) (1)}

This license only allowing others to download your works and share them with others as long as they credit you, but they can't change them in any way or use them commercial. 


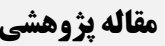

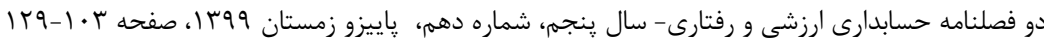

\section{تاثير منبع كنترل و تعهدسازمانى بر بذيرش رفتار ناكار آمد حسابرسى بر اساس تئورى رفتار برنامه ريزى شده}

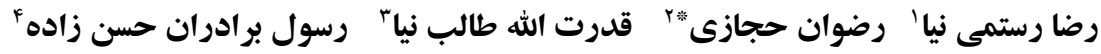

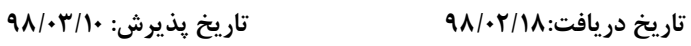

\begin{abstract}
جكيده
يذيرش رفتار ناكارآمد حسابرسى، يذيرش هركونه اقدامى است كه مطابق با استانداردهاى

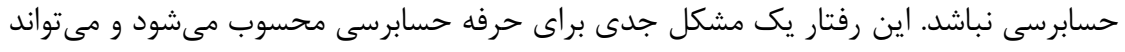

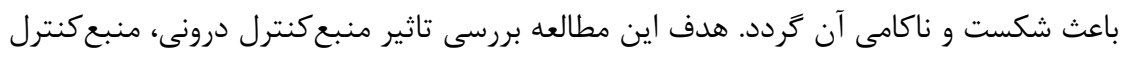

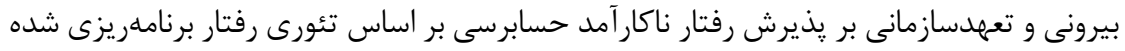

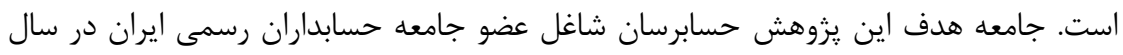

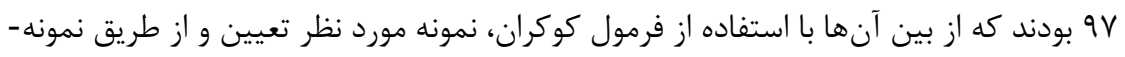

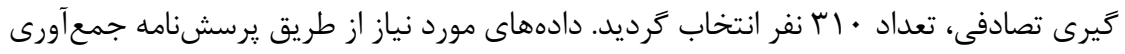

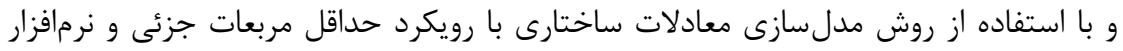

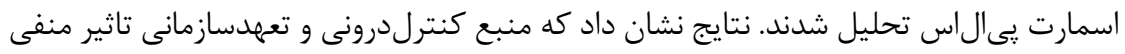

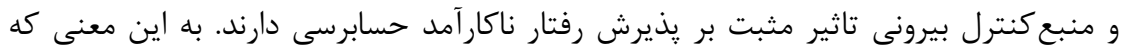

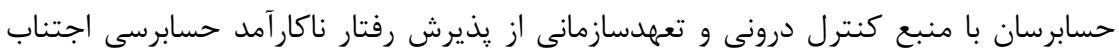

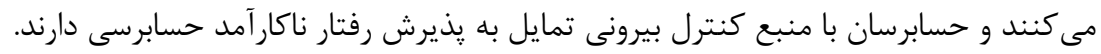
وازههاى كليدى: يذيرش رفتار ناكار آمد حسابرسى، تعهدسازمانى، منبع كنترل، شانهخالى كردن،

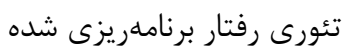

'دانشجوى دكترى حسابدارى، كروه حسابدارى، واحد بين المللى كيش، دانشًاه آزاد اسلامى، جزيره كيش، ايران (r.rostaminia@iau-shoushtar.ac.ir) "استاد حسابدارى، مدرس دانشخاه آزاد اسلامى واحد بين المللى كيش (نويسنده مسئول)، Hejazi33@gmail.com "دانشيار حسابدارى، واحد علوم و تحقيقات، دانشخاه آزاد اسلامى، تهران، ايران (gh_talebnia@yahoo.com) (drh313@gmail.com) (دانشيار حسابدارى، واحد تبريز، دانشخاه آزاد اسلامى ، تبريز، ايران) 


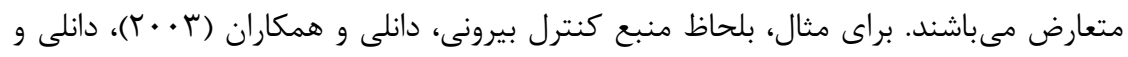

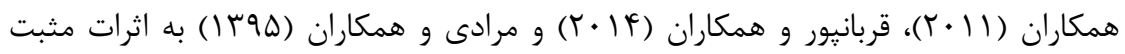

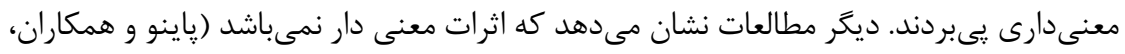

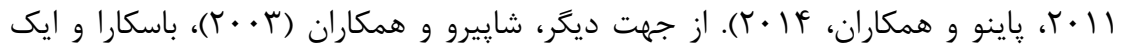

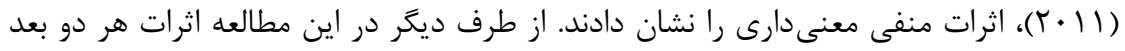

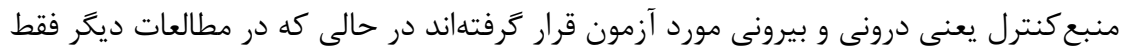
بعد بيرونى منبع كنترل آزمون شده است

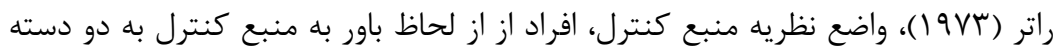

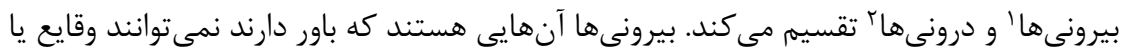

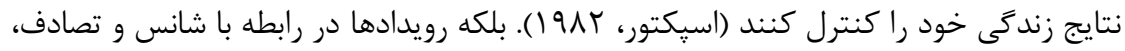

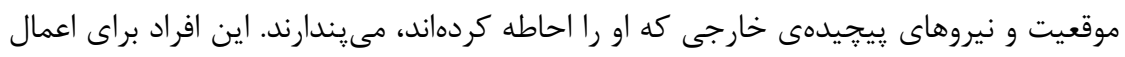

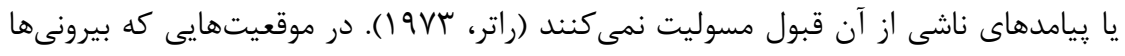

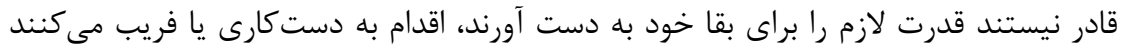

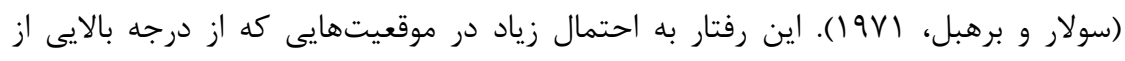

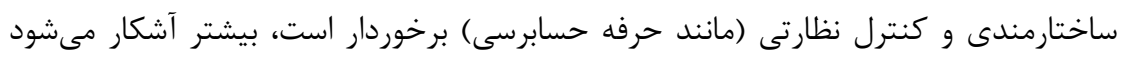

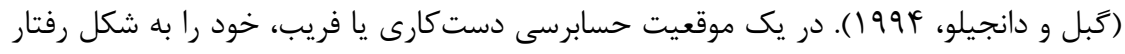

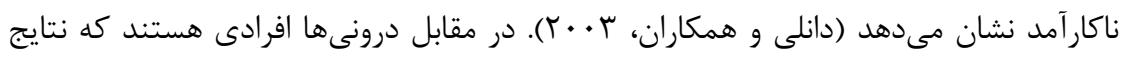

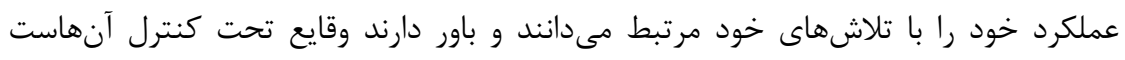

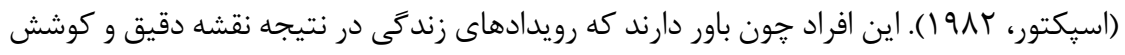

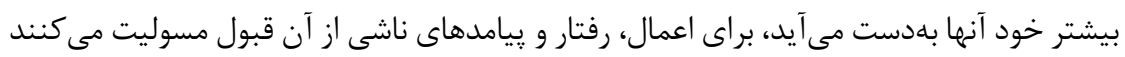

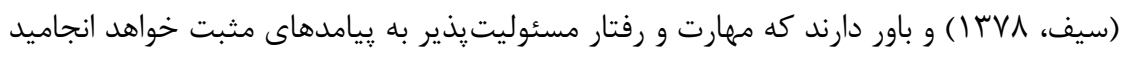

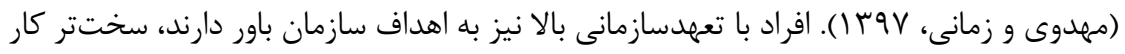

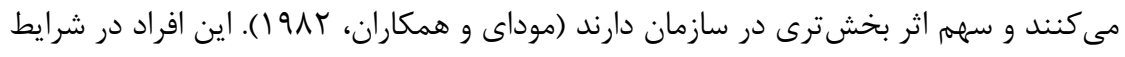

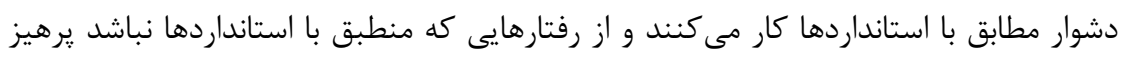

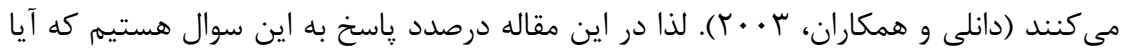

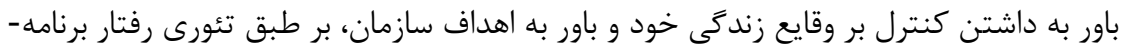

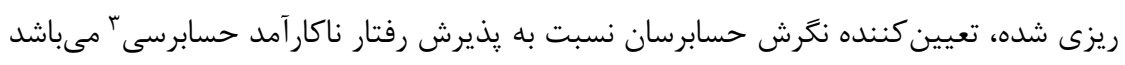

${ }^{1}$ Externals

${ }^{2}$ Intrenals

${ }^{3}$ Acceptance of Dysfunctional Audit Behavior 
يا خير؟ به عبارت ديكر آيا منبع كنترل بيرونى، منبع كنترل درونى و تعهد سازمانى بر يذيرش

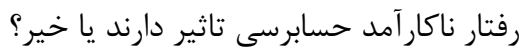

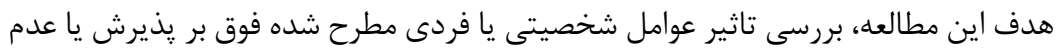

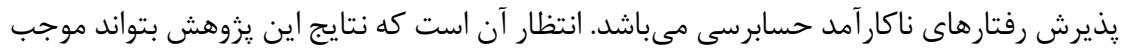

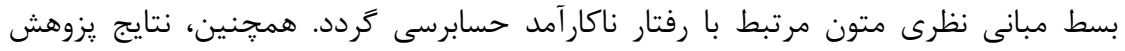

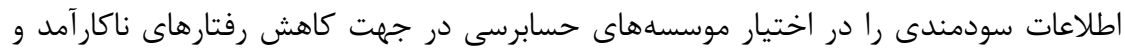
افزايش كيفيت حسابرسى قرار دهد.

\section{r-مبانى نظرى و يِيشينه يزوهش - ت تئورى رفتار برنامهريزى شده}

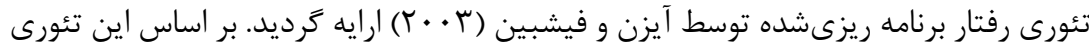

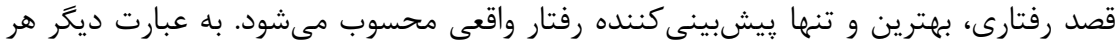

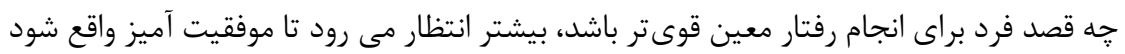
(هادى زاده مقدم و همكاران، بوج ا). اين تئورى از سازههاى تعيين كننده تمايل رفتارى (قصد

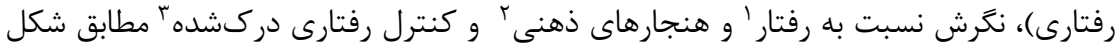
ا تشكيل شده است.

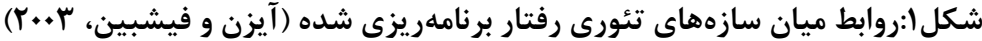

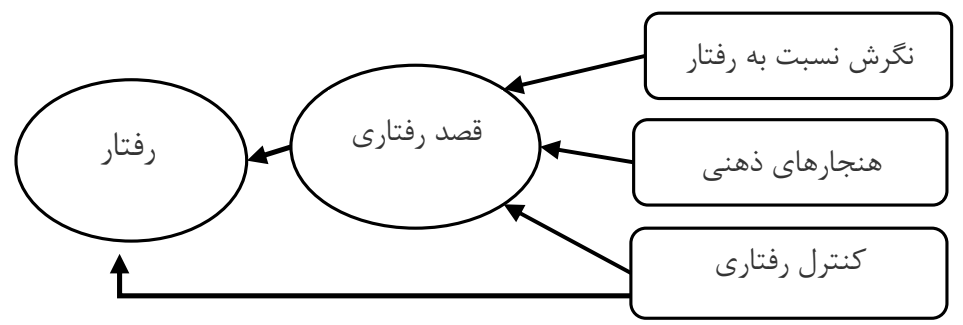

مطابق اين تئورى، نكرش، از باورهاى مرتبط با يِيامدهاى انجام اعمال و رفتارهايى ساخته

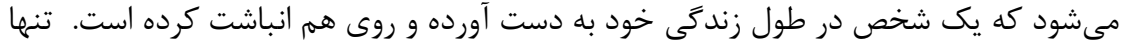

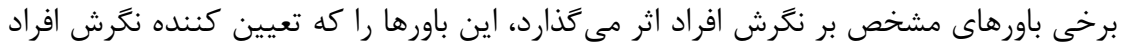

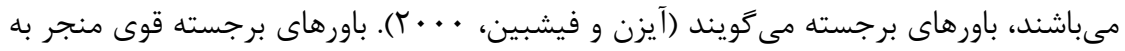

${ }^{1}$ Attitude Toward Behavior

${ }^{2}$ Subjective Normal

${ }^{3}$ Perceived behavioral control 
نخرش هاى مثبت نسبت به يك رفتار مشخص مى شوند و بر عكس. هنجارهاى ذهنى يا هنجارهاى

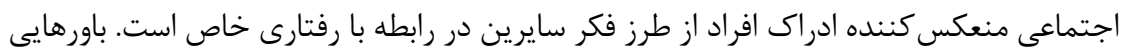
كه تحت تاثير هنجارهاى ذهنى شكل مى كيرند، باورهاى هنجارى ناميده مى شوند(هادى زادي دادي

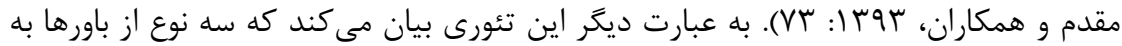

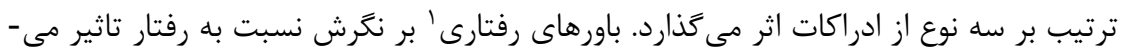

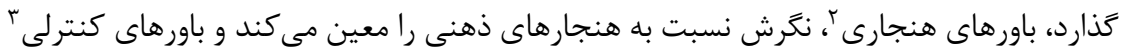

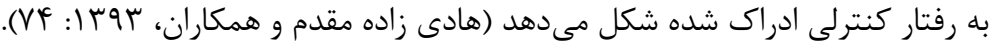

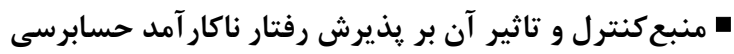

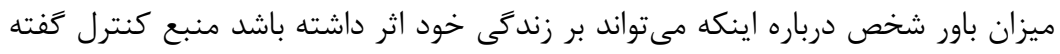
مىشود كه با نامهاى مكان كنترل، موضعقدرت، كانون كنترل و مسندمهار معرفى مىشودا

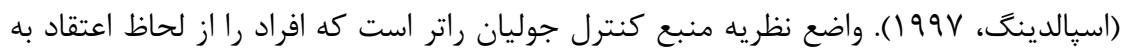

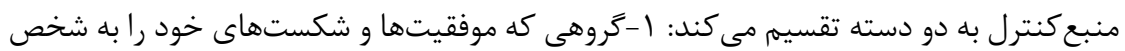
خود (كوششها يا توانايى شخصى) نسبت مى دهند افراد داراى منبع كنترل درونى ناميده مى مئ

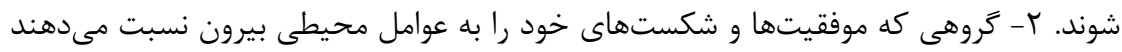

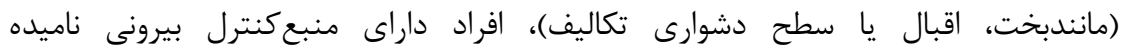

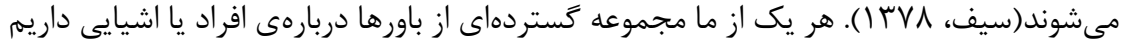

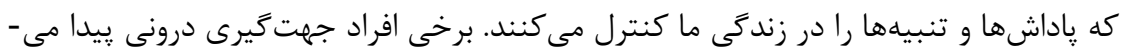

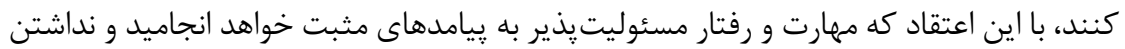

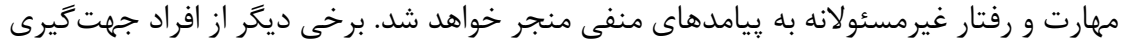

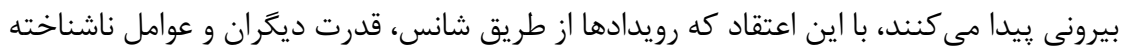

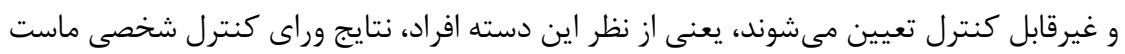

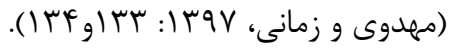

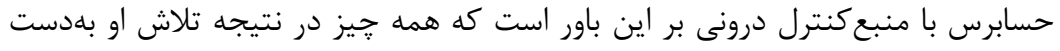

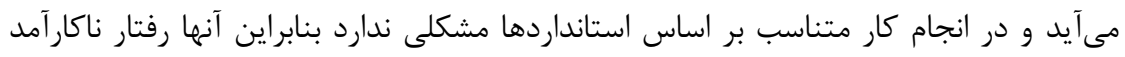

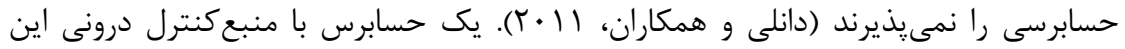

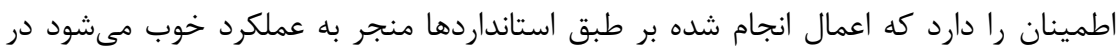

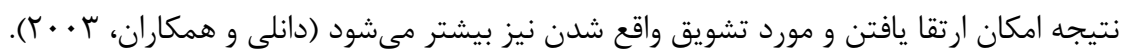

${ }^{1}$ Behavioral Beliefs

${ }^{2}$ Normative Beliefs

${ }^{3}$ Control Beliefs 
اين نكَرش در حسابرسان انغيزه ايجاد مى كند تا رفتار ناكارآمد حسابرسى را نيذيرد. حسابرس با

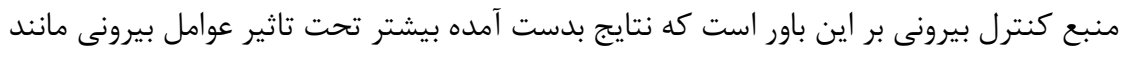

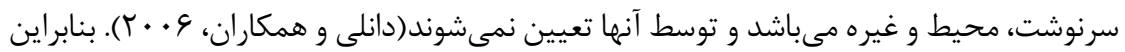

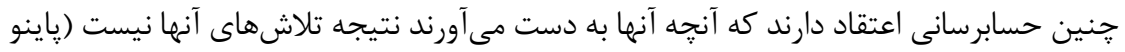

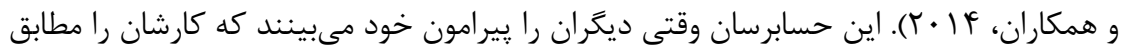

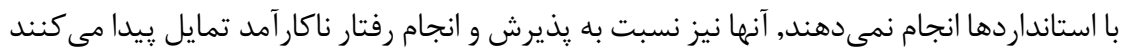

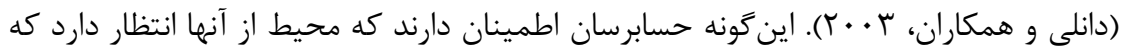

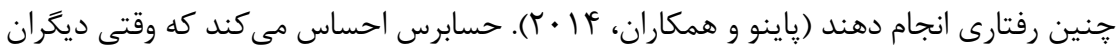

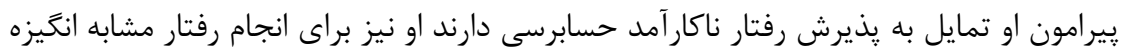

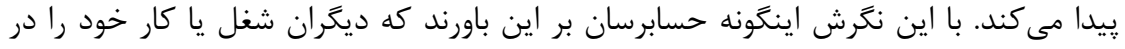

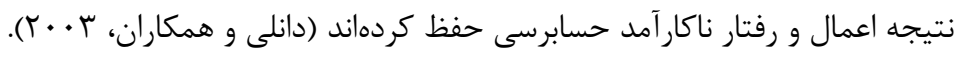

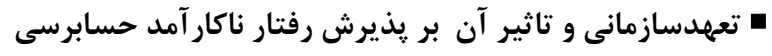

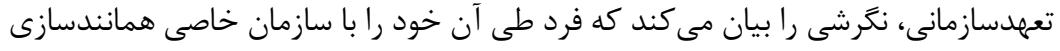

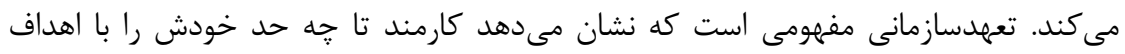

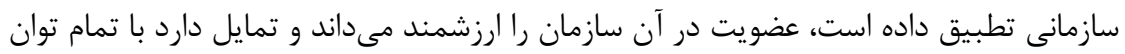

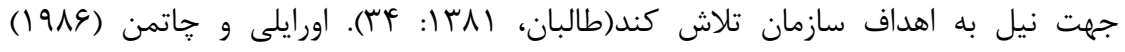

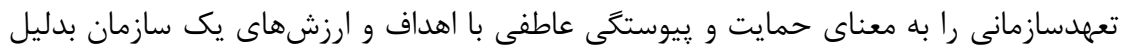

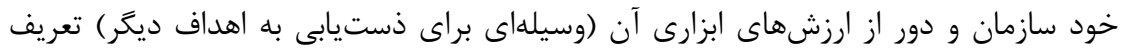

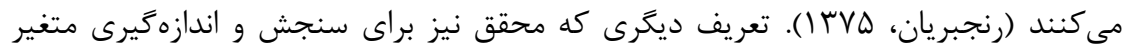

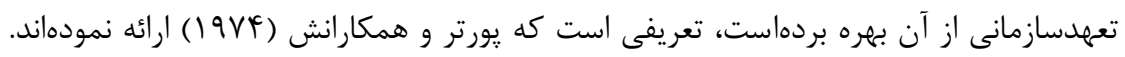

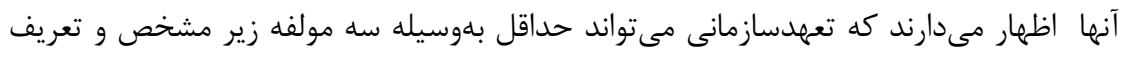

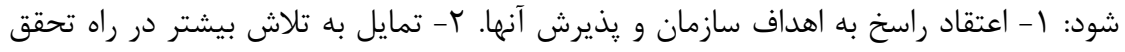

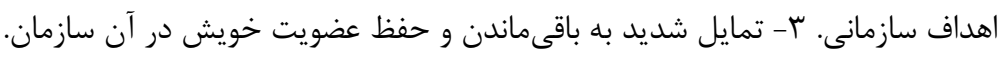

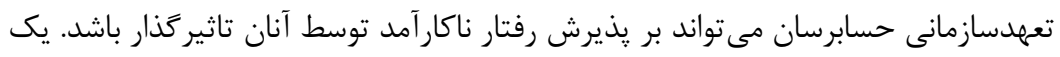

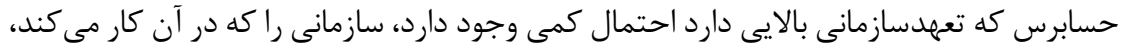

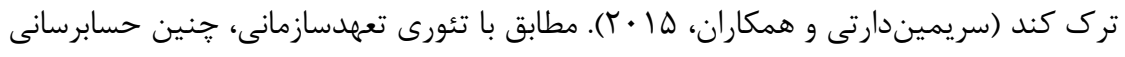

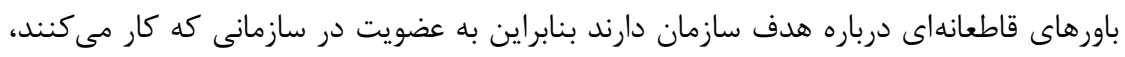

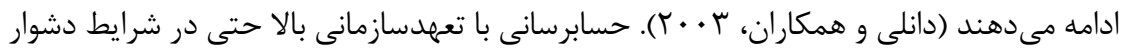

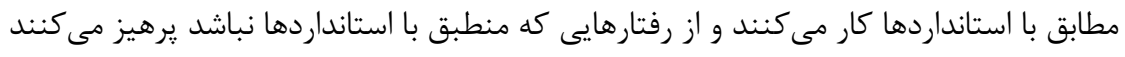


(دانلى و همكاران، 9. • ()). مالون و روبرتس (1999) عقيده دارند حسابرسانى با تعهد سازمانى

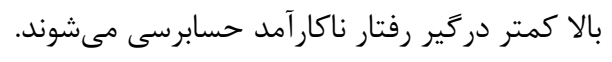

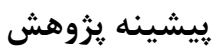

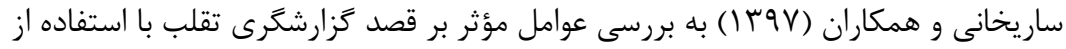

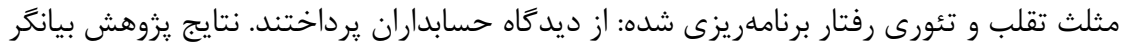

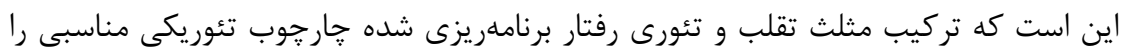
براى بيشبينى قصد كزارشكرى تقلب فراهم مى آورد.

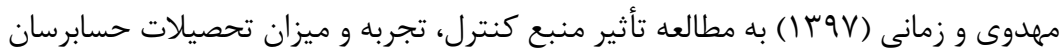

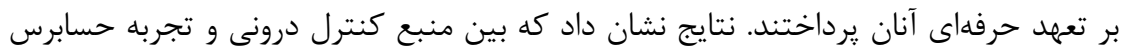

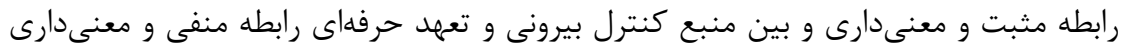

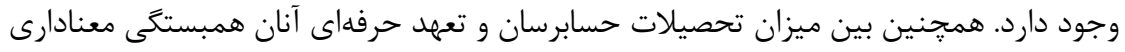

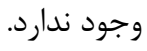

لارى و همكاران (99 إ) به بررسى رفتار ناكارآمد حسابرسان: آثار جو اخلاقى مديران و

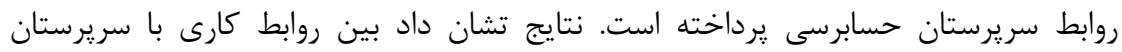

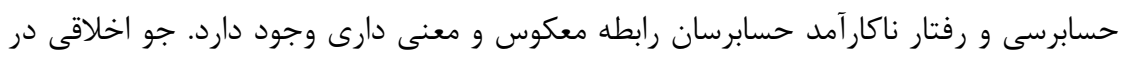

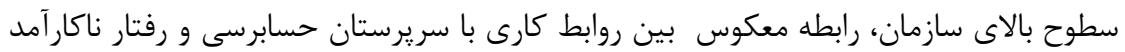
حسابرسان را كم مى كند.

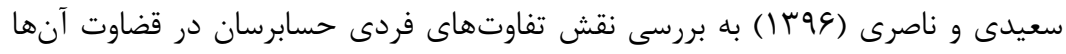

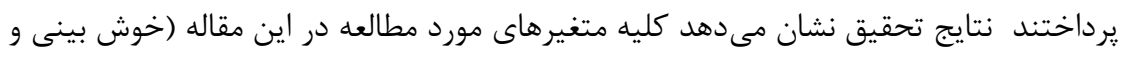

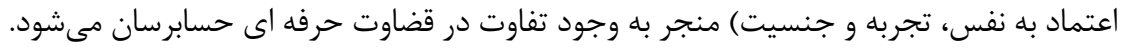

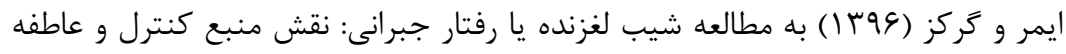

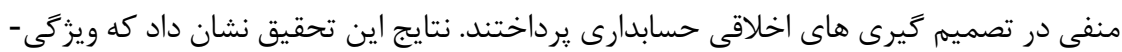

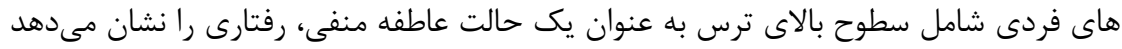

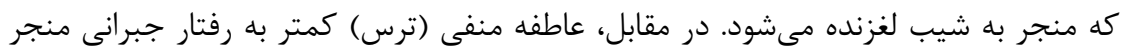

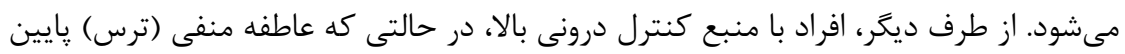
باشد رفتار جبرانى را نشان مى اندهند.

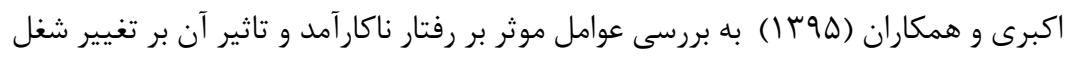

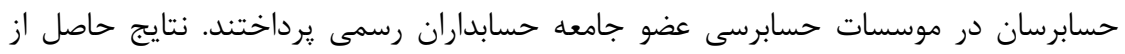

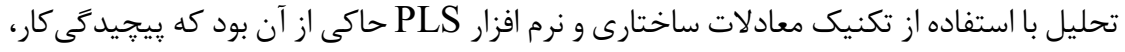

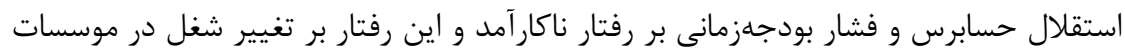


حسابرسى تاثير دارد. ضمن اينكه اهميت مشترى بر رفتار ناكار آمد در اين موسسات مورد تاييد قرار نكرفته است.

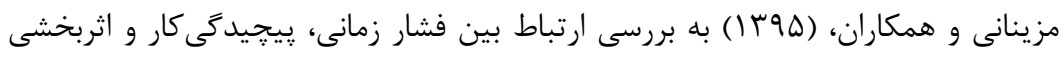

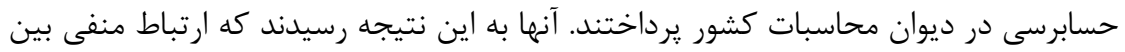

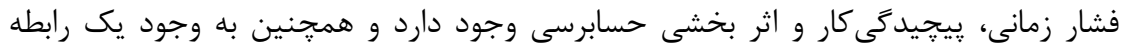

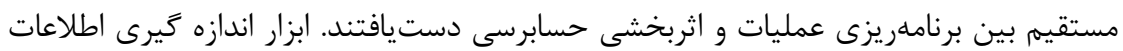

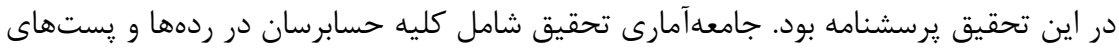

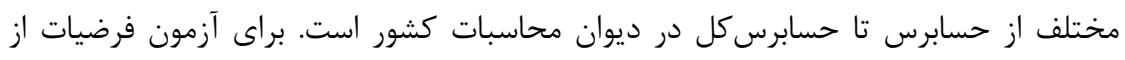
ضريب همبستكى و ركرسيون خطى ساده استفاده شدهاست.

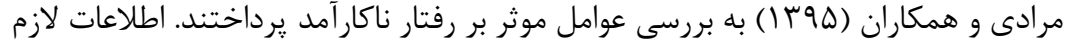

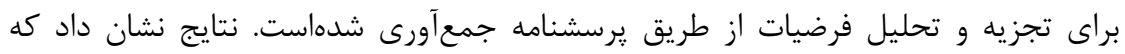

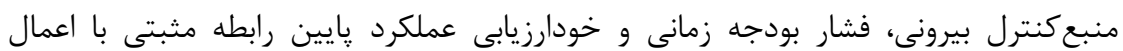

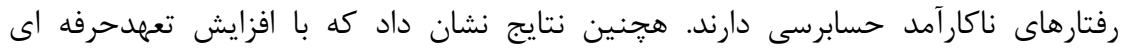

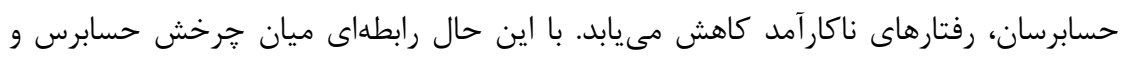
سيستم كنترلى سازمان يافت نشد.

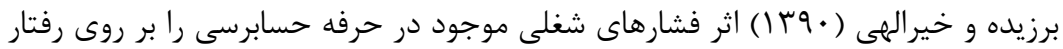

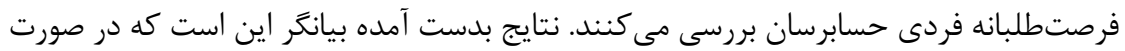

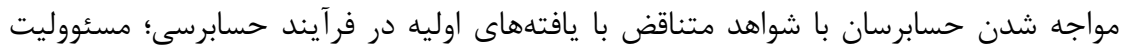

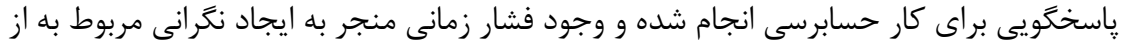

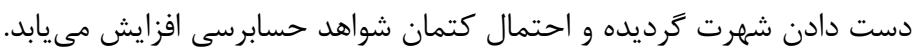

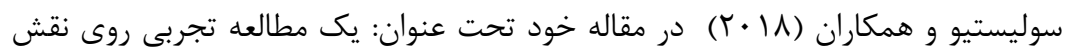

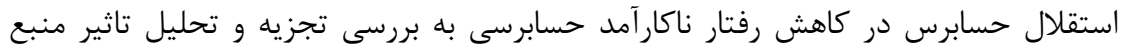
كنترل و تعهد حرفهاى روى رفتار ناكارآمد حسابرسى با در نظر كرفتن نقش تعديلكر استقلال

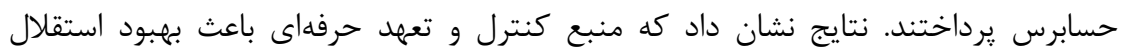

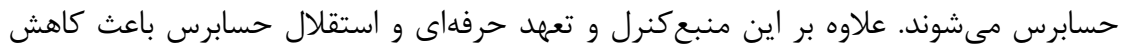

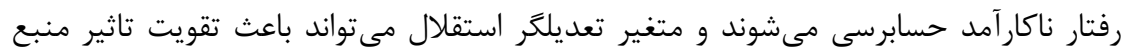
كنترل و تعهد حرفهاى در كاهش رفتار ناكارآمد حسابرسى شونى

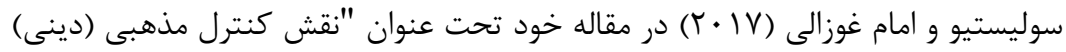

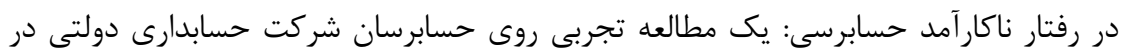

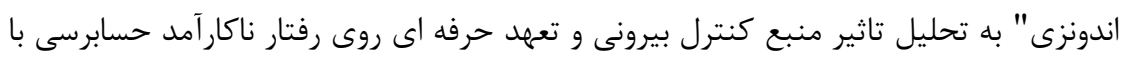


نقش ميانجى كنترلمذهبى ثرداختند. نتيجه اين مطالعه نشان داد كه تا حدى، منبع كنترل

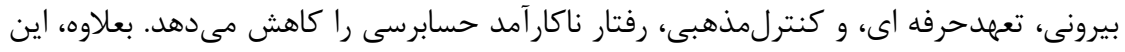

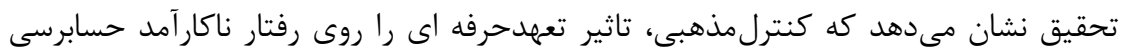

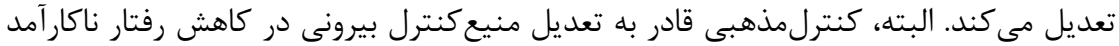
حسابرسى نيست.

سوانستروم (1) • ؟) در مطالعه اى تحت عنوان " فشار زمانى، فعاليتهاى آموزشى و رفتار

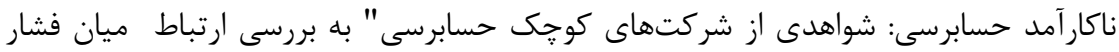

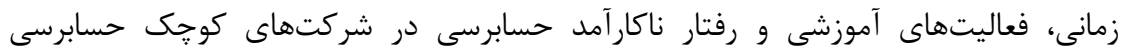

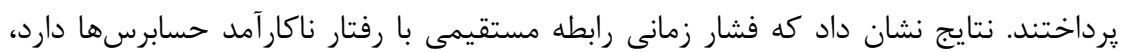

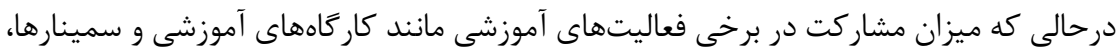

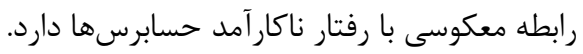

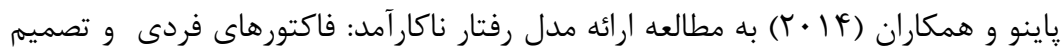
مالى اخلاقى يرداختند. در اين مطالعه به بررسى فاكتورهاى خاصى ماند مانند منبع كنترل،

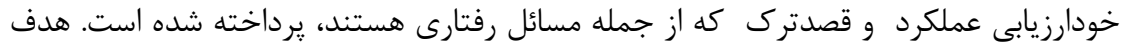

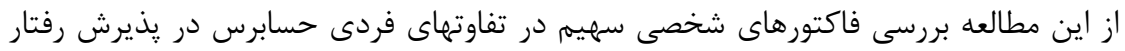

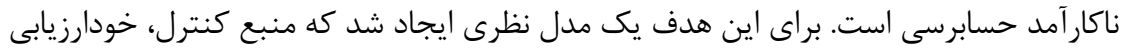

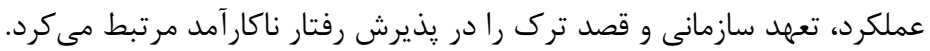

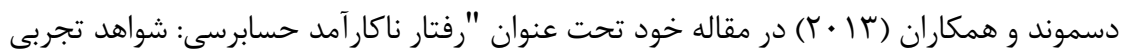

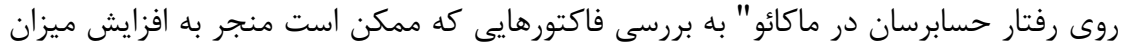

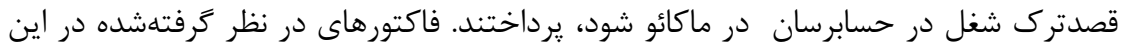

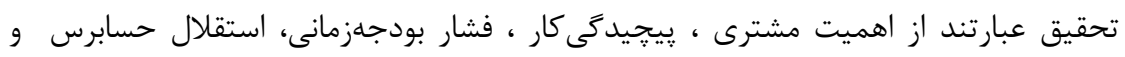

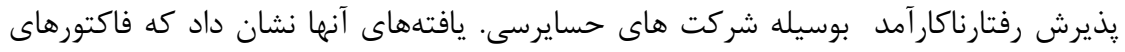

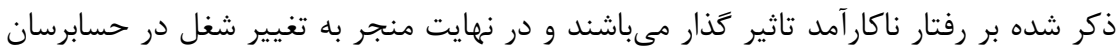

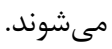
دانلى و همكاران (9 • (Y) به مطالعه نكرش شايى بسوى رفتار ناكار آمد: تاثيرات منبع كنترل

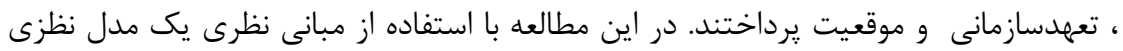

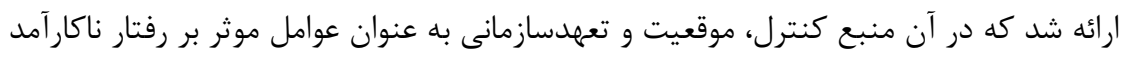
شناسايى شدند. با استفاده از طرح متقابل سازمانى و يك تكنيك تحليل مسير نتايج بررسى از rا 11 حسابرس از مدل نظرى ارائه شده پشتيبانى كرد. 


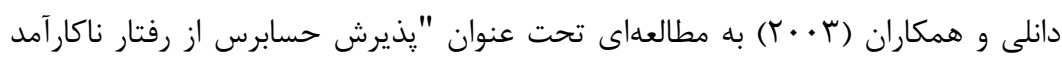

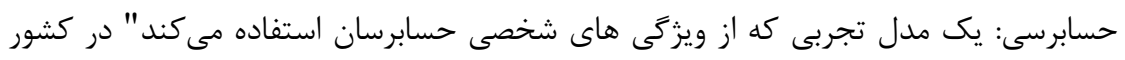

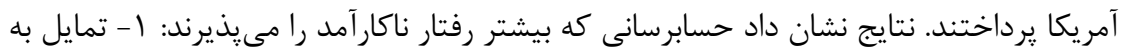

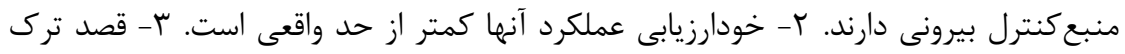
شغل در آنها بيشتر است.

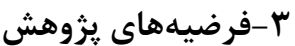

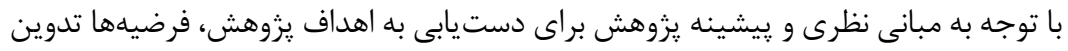

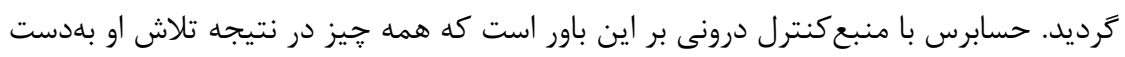

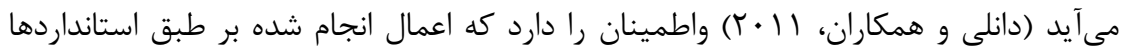

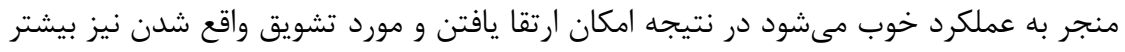

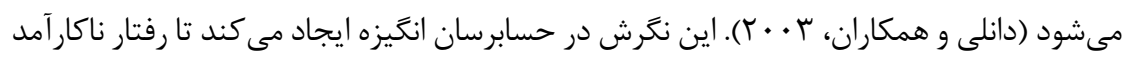

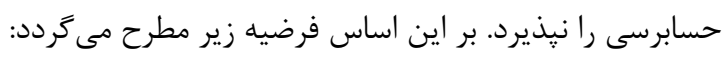

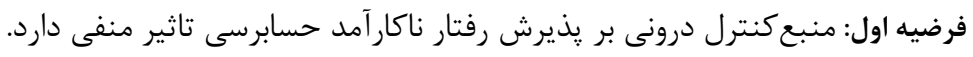

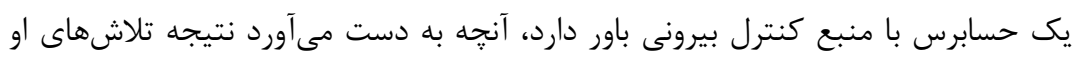

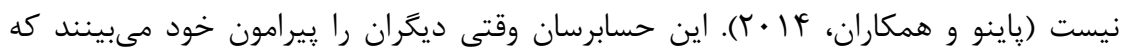

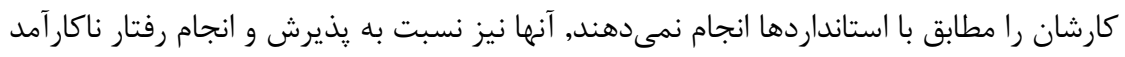

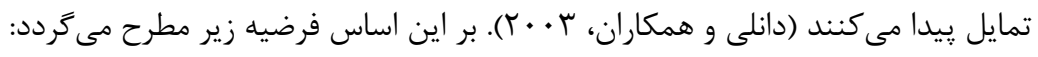

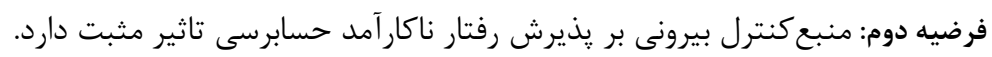

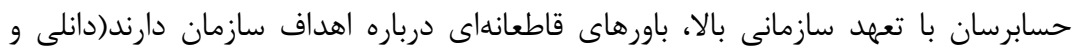

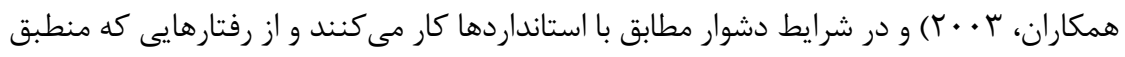

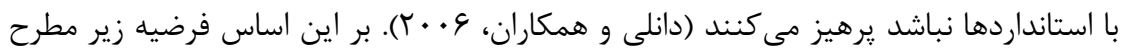

$$
\text { مى כر مد: }
$$

فرضيه سوم: تعهدسازمانى بر يذيرش ردفار رفتار ناكار آمد حسابرسى تاثير منفى دارد.

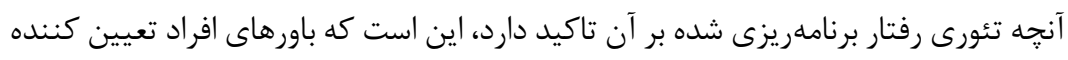

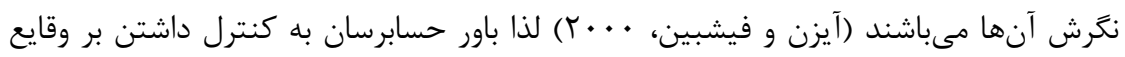

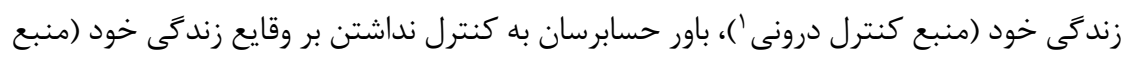

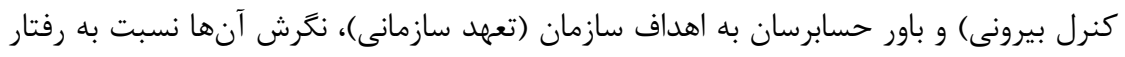

${ }^{1}$ Internal Locus of Control 
ناكار آمد را شكل مى دهد و هَكونكى نكرش حسابرسان بر قصد رفتارى (يذيرش يا عدم بذيرش

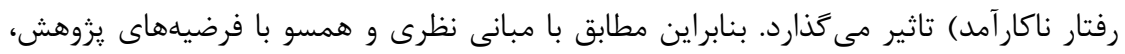
مدل مفهومى بزوهش به صورت شكل r ت تدوين كرديد:

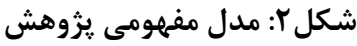

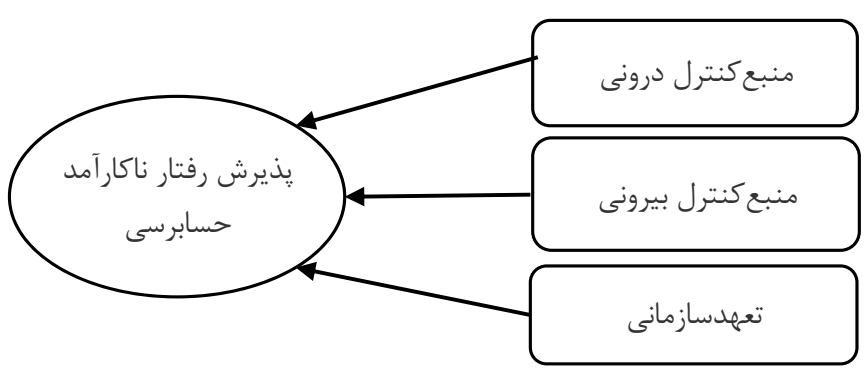

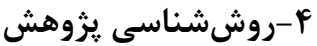

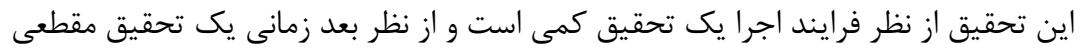

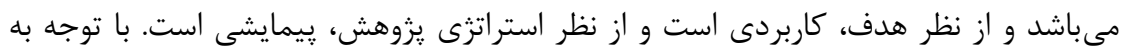

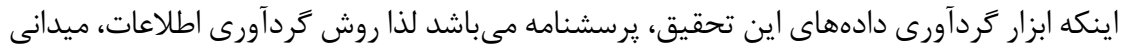

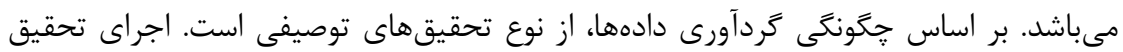

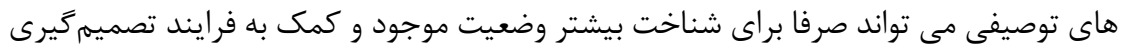

باشد. با توجه به انواع طبقهبندى تحقيقات توصيفى، اين تحقيق از نوع همبستكى مى باشيد.

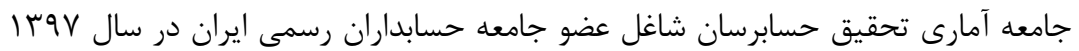

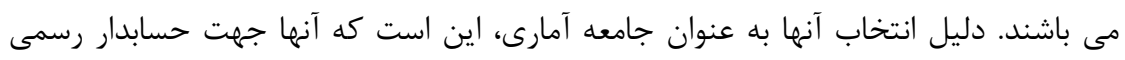
شدن نيازمند احراز شرايط خاص از جمله قبولى در آزمون حسابدار رسمى و دارا بودن سابقه آنها

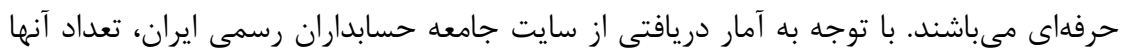

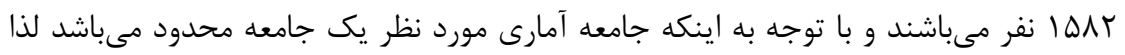
براى تعيين حجم نمونه از فرمول كوكران و روش نمونه گيرى تصادفى استفاده گرديد و و تعداد

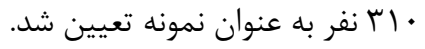
در اين تحقيق ابتدا مبانى نظرى به صورت كتابخانهاى و با استفاده از مجلات و كتابهاي

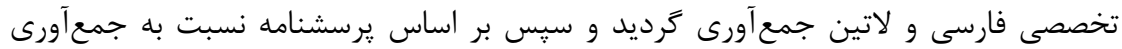

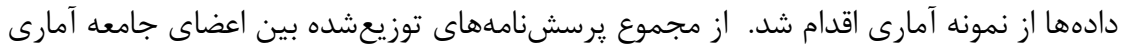


تعداد عاس برسشنامه جمع آورى شد و بعد از بررسى آنها و حذف پرسشنامههاى ناقص، تجزيه

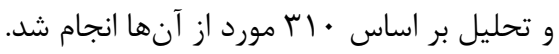

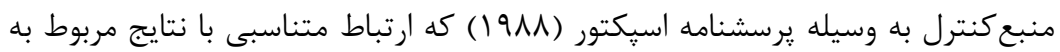

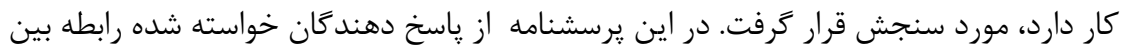

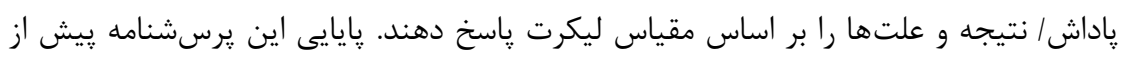

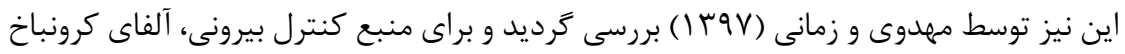

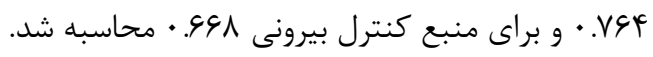

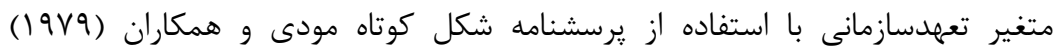

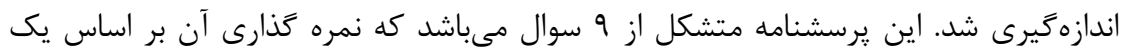
مقياس ليكرت انجام كرفت.

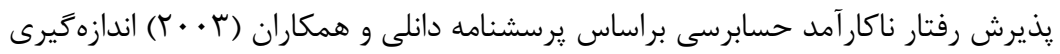

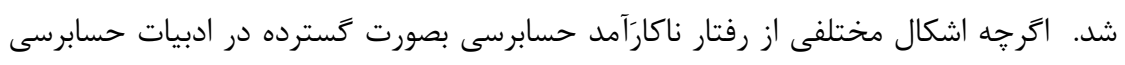

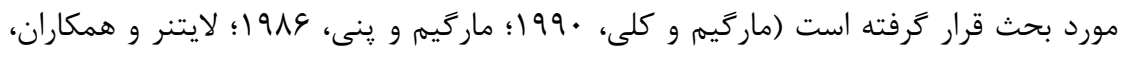

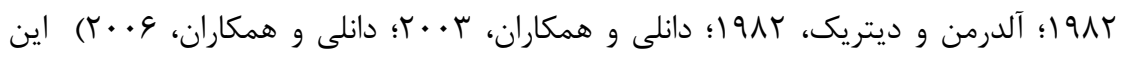

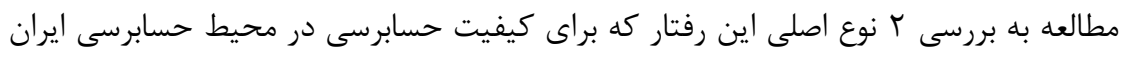

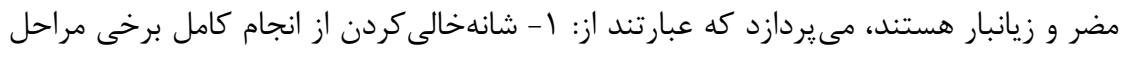

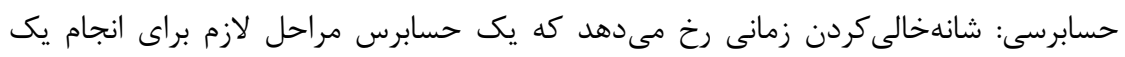

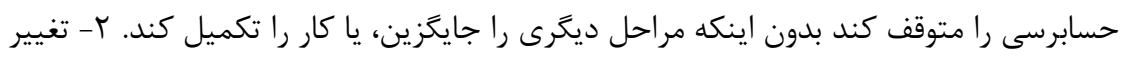

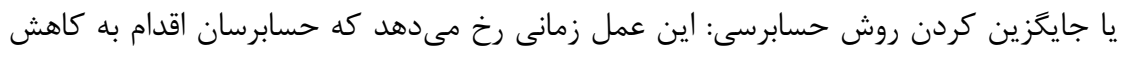

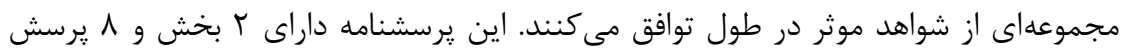

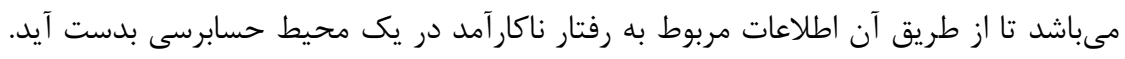

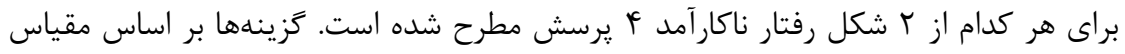
ليكرت طراحى شدهبودند. براى اطمينان از روايى محتوايى و ظاهرى يرسشنامنامه، ويرايش اوليه آن در اختيار صاحب-

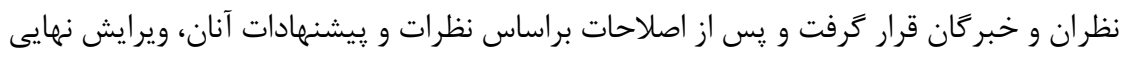

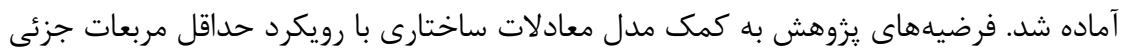

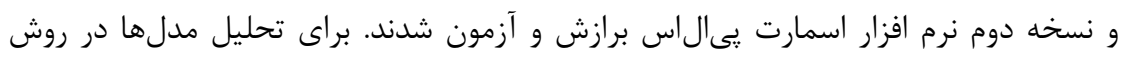

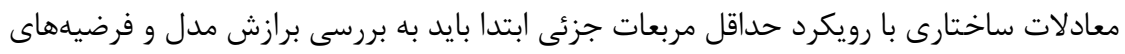

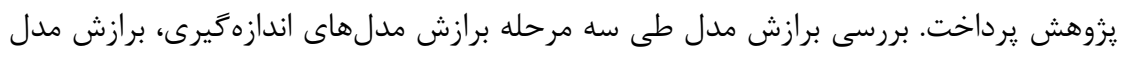
ساختارى و برازش مدل كلى انجام مى بردود. 

رستمى نيا و همكاران، تاثير منبع كنترل و تعهدسازمانى بر يذيرش رفتار ناكارآمد حسابرسى...

\section{ه- يافتههاى يزوهش}

به منظور شناخت بهتر جامعه مورد مطالعه، جدول I اطلاعات جمعيت شناختى ياسخ

$$
\text { دهند }
$$

جدول ا: اطلاعات جمعيت شناختى

\begin{tabular}{|c|c|c|c|c|c|}
\hline & \multicolumn{2}{|c|}{ سطح تحصيلات ياسخ دهندًان } & \multicolumn{3}{|c|}{ توريع سنى ڤاسخ دهندگان } \\
\hline درصد & تعداد & مدرك تحصيلى & درصد & تعداد & سن \\
\hline$\%$ \% ^.ब & 119 & كارشناسى & $\%(r)$ & $9 \Delta$ & كمتر از هـ \\
\hline$\% .09$ & IN & كارشناسى ارشد & $\%$ & $|r|$ & از \\
\hline$\%$ Y.Q & $\Lambda$ & دكترى & $\%$ & ir & بيش از ه \\
\hline$\%$ & r. & جمع & $\% 1+$. & 1. & جمع \\
\hline \multicolumn{3}{|c|}{ تجريه ياسخ دهندًان } & \multicolumn{3}{|c|}{ موقعيت شغلى ڤِاسخ دهندگًان } \\
\hline درصد & تعداد & ميران تجربه & درصد & تعداد & موقعيت \\
\hline$\% 10$ & 19 & از צ تا • ا سال & $\%$ \% & 9 . & حسابرس ارشد \\
\hline$\%$ \% & $\Lambda$. & از 1 1 تا ها سال & $\%$ \% & $\wedge \vee$ & سريرست \\
\hline$\%$ & 99 & از عا تا •r سال & $\%$ & VI & سريرست ارشد \\
\hline$\%$ r & 11. & از آ تا \&r سال & $\%$ & gr & 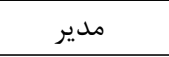 \\
\hline$\%$ & $\Lambda$ & از צr تا •r سال & & & \\
\hline$\%$ & m. & جمع & $\%$ & m. & جمع \\
\hline
\end{tabular}

براى برازش مدل اندازهگيرى بايد از سه معيار يايايى، روايى همخرا و روايى واگرا استفاده كرد. براى سنجش پايايى مدل، به بررسى پايايى تركيبى و آلفاى كرانباخ پرداخته شدهاست.

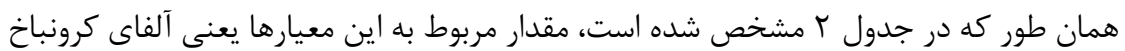

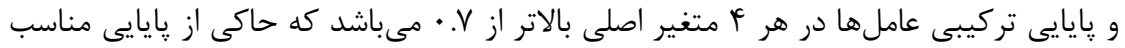

جدول r: يايايى تركيبى، آلفاى كرونباخ و ميانگين واريانس

\begin{tabular}{|c|c|c|c|}
\hline $\begin{array}{c}\text { ميانغين واريانس } \\
\text { (AVE) }\end{array}$ & آلفاى كرونباخ & هايايى تركيبى & عامل هاى تحقيق \\
\hline$\cdot . \wedge \cdot$ & $\cdot . \wedge \cdot$ & .99 . & منبع كنترل بيرونى \\
\hline$\cdot . \vee \wedge \wedge$ & $\cdot . \vee \wedge \wedge$ & $.9 \Delta \mathrm{V}$ & منبع كنترل درونى \\
\hline $.9 \mathrm{~V}$. & $.9 \mathrm{~V}$. &. $.9 F r$ & رفتار ناكارآمد حسابرسى \\
\hline •VIT & . & $\cdot .9 \Delta V$ & تعهد سازمانى \\
\hline
\end{tabular}


روايى يرسشنامه به كمك دو معيار روايى همخرا و روايى واگرا كه مخصوص مدلسازى

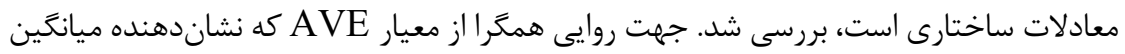

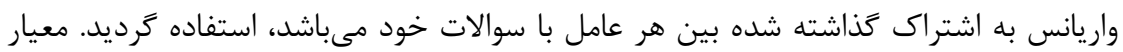

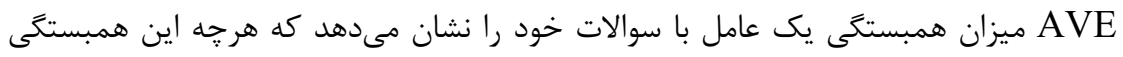

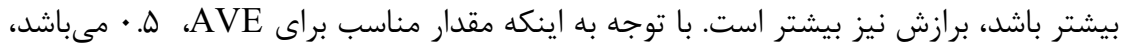

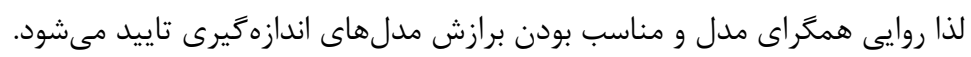

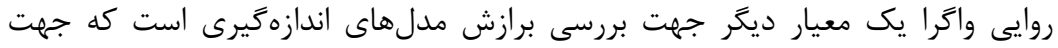

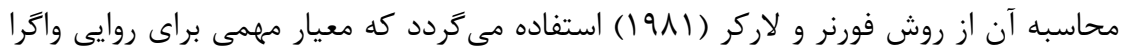

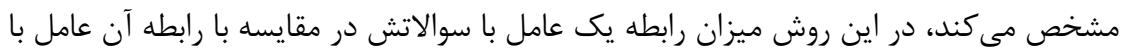

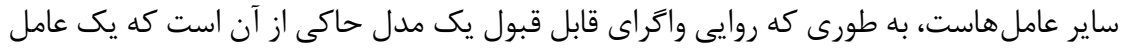

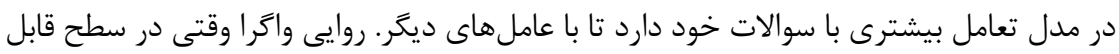

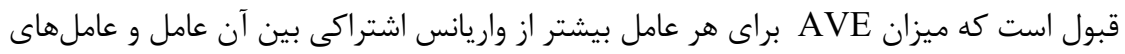

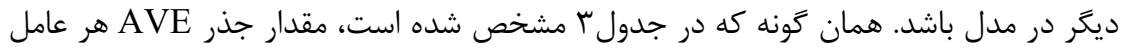

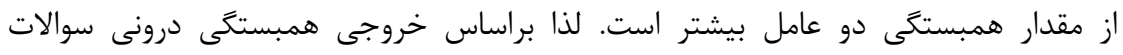

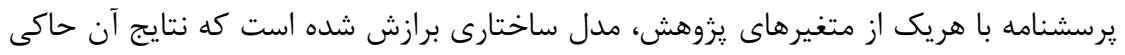
از روايى درونى يرسشنامه است. جدول r: روايى واترا به روش فورنل لاركر

\begin{tabular}{|c|c|c|c|c|}
\hline سازمانى & رفابر ساكى آمد & منبع كنترل & منبع كنترل & متغيرهاى تحقيق \\
\hline & & &. .191 & منبع كنترل بيرونى \\
\hline & & $\cdot . \wedge \wedge \mathrm{V}$ & $\cdot .+41$ & منبع كنترل درونى \\
\hline & $\cdot .111$ & $\cdot .9 \Lambda \cdot-$ & $\cdot . \varphi \Delta \Lambda$ & رفتار ناكار آمد حسابرسى \\
\hline$\cdot .14 f$ & $\cdot . \vee V \Lambda-$ & $\cdot .411$ & $\cdot v 1 \cdot-$ & تعهد سازمانى \\
\hline
\end{tabular}

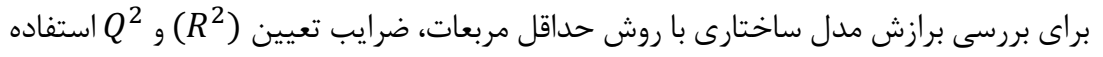

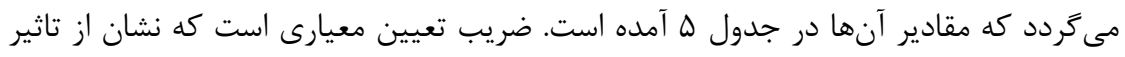

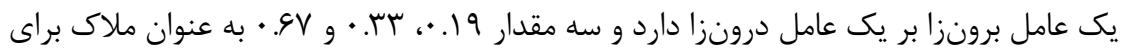

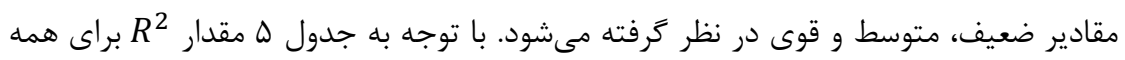

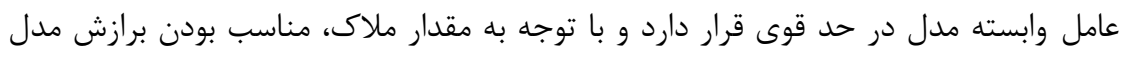
ساختارى، تاييد مىشود. 
معيار

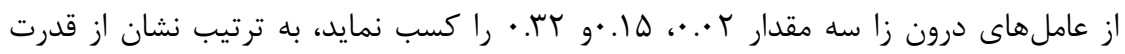

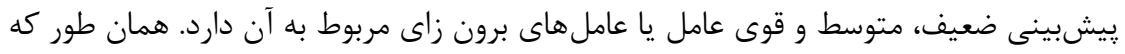

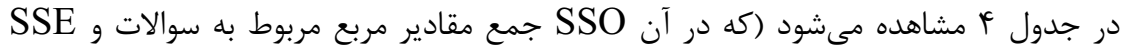

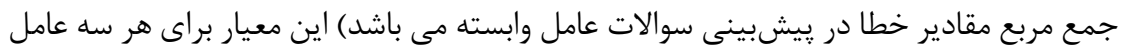

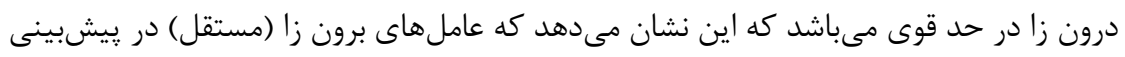

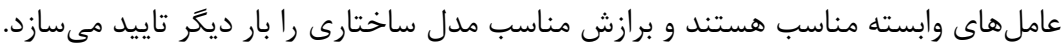

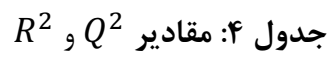

\begin{tabular}{|c|c|c|c|c|}
\hline ضريب تعيين R & 1-SSE/SSO & $\begin{array}{c}\text { مربوط مقادير مربع سوالات } \\
\text { SSE }\end{array}$ & $\begin{array}{c}\text { مقادير مربعا } \\
\text { SSO }\end{array}$ & عامل هاى تحقيق \\
\hline $.9 \vee \wedge$ & $\cdot .0 \cdot 9$ & ITTE.TTI & TFA. & ناكار آمد حسابرسى \\
\hline
\end{tabular}

برازش كلى مدل

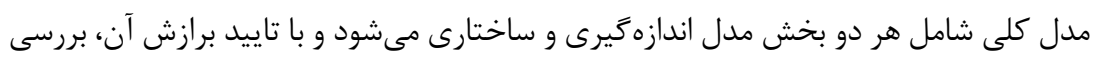

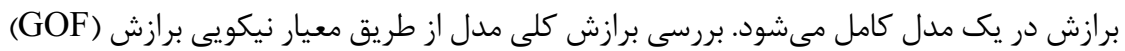

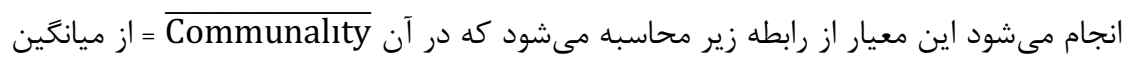

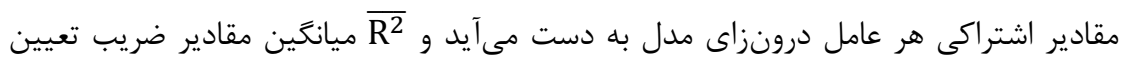
عامل هاى درون زاى مدل است.

$$
\text { GOF }=\sqrt{\overline{\mathrm{R}^{2}} * \overline{\text { Communality }}}=\sqrt{0.767 * 0.670}=0.716
$$

با توجه به سه مقدار ا •.•، هז. • و צr. • كه به عنوان مقادير ضعيف، متوسط و قوى براى

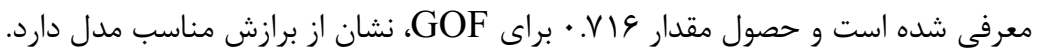

\section{نتايج آزمون فرضيدهاى بزوهش}

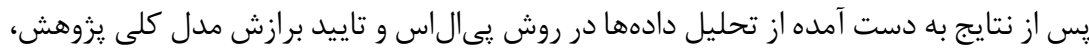

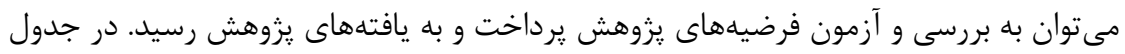

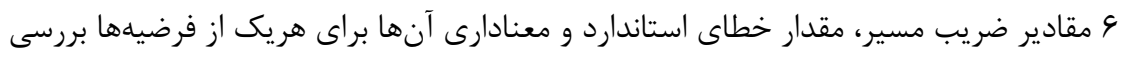

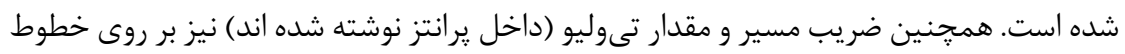

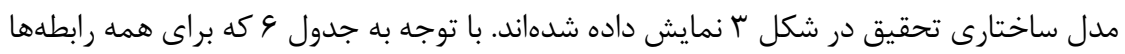

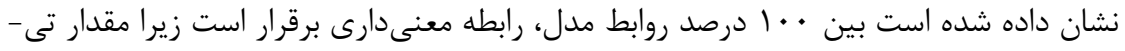


وليو براى اين رابطهها بيشتر از وه. 1 مىباشد و از آنجا كه . ل1 درصد روابط تاييد شده اند در نتيجه برازش مدل ساختارى در حد مطلوبى مى باشد. شكل r: مدل نهايى تحقيق

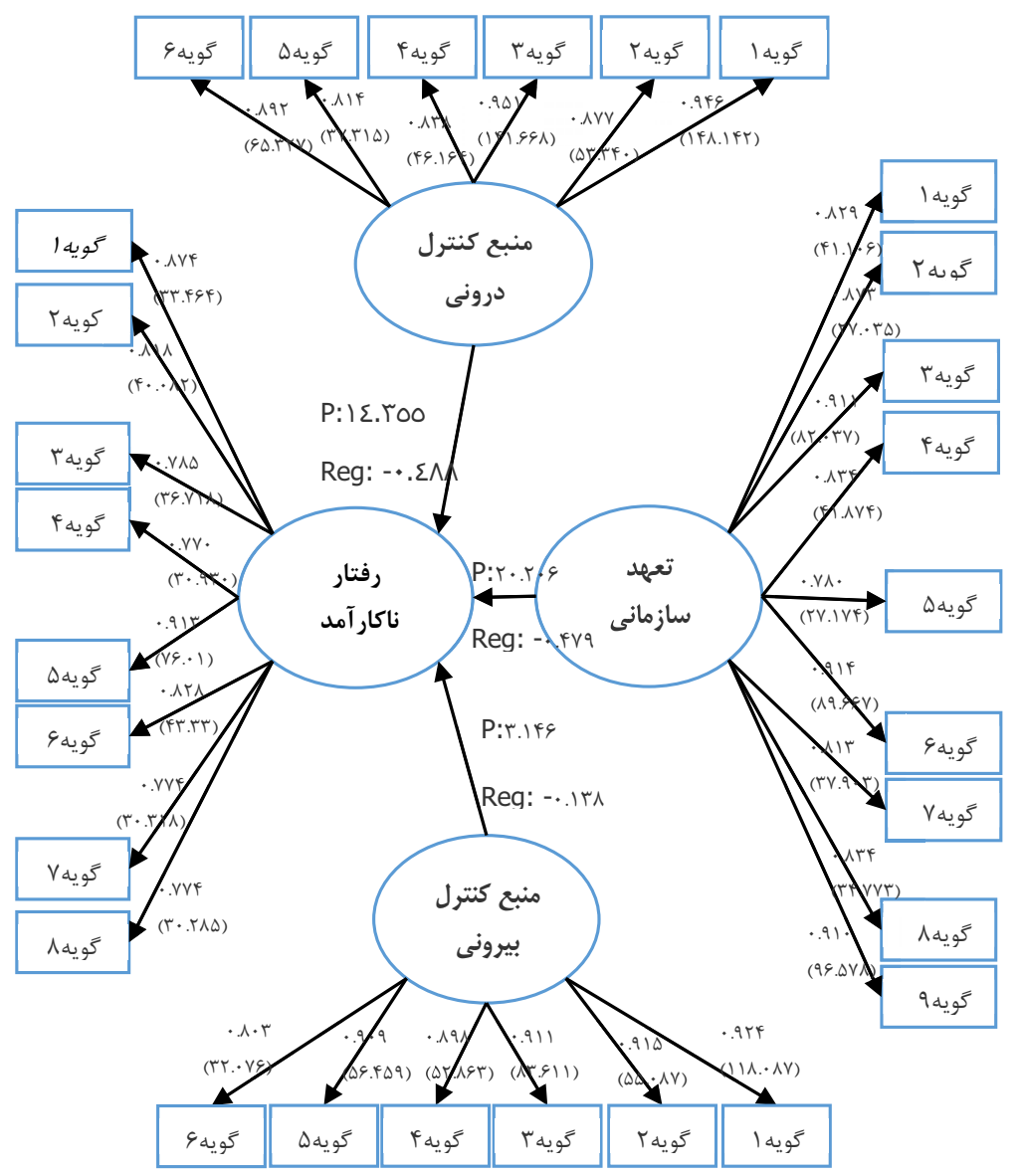

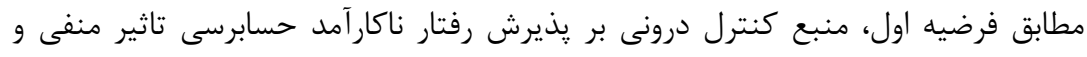

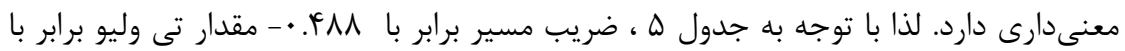

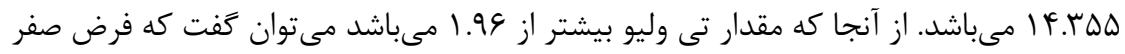

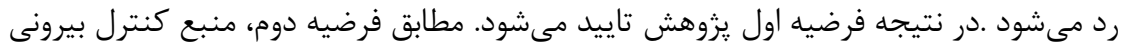

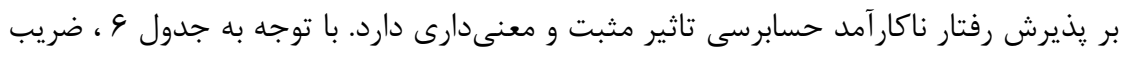

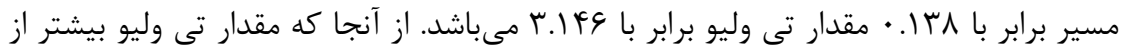


1 ا. مىباشد مىتوان كفت كه فرض صفر رد مىشود در نتيجه فرضيه دوم يزوهش تاييد مى-

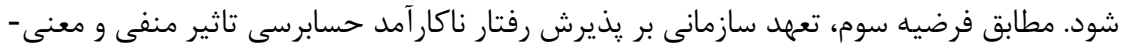

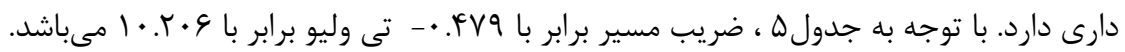

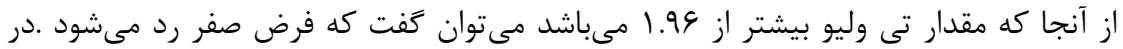

$$
\text { نتيجه فرضيه سوم يزوهش تاييد مىشود. }
$$

جدول ه: ضرايب استاندارد و معنى دارى و خطاى استاندارد

\begin{tabular}{|c|c|c|c|c|}
\hline نتيجه & آزمون تى مقدار & ختاندارد & ضر ايب مسير & بررسى رابطه ها درون مدل ساختارى تحقيق \\
\hline رد فرض صفر & $\mid f . r \Delta \Delta$ & $\cdot \cdot r y$ & $-\cdot . \uparrow \wedge \Lambda$ & منبع كنترل درونى ج رفتار ناكارآ آمد حسابرسى \\
\hline رد فرض صفر & r.149 & 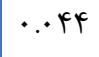 & $\cdot .1 \mathrm{r}$ & منبع كنترل بيرونى ج رفتار ناكارآمد حسابرسى \\
\hline رد فرض صفر & $1 \cdot . r \cdot 4$ & $\because \leftrightarrow v$ & $-\cdot . p \vee q$ & تعهد سازمانى ج رفتار ناكار آمد حسابرسى \\
\hline
\end{tabular}

\section{9- ونتيجه كيرى و بحث}

اين مطالعه به بررسى تاثير منبع كنترل درونى، منبع كنترل بيرونى و تعهلدسازمانى بر يذيرش رفتار ناكارآمد حسابرسى در قالب سه فرضيه بر اساس تئورى رفتار برنامهريزى شده، يرداخت.

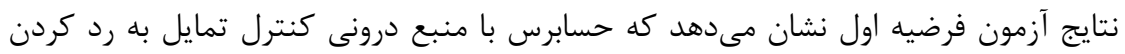

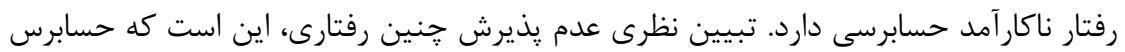

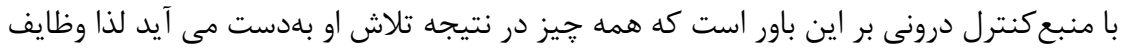

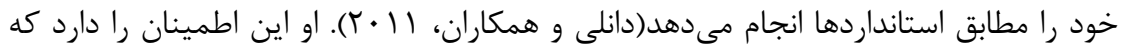

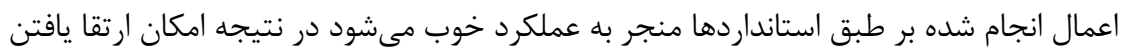

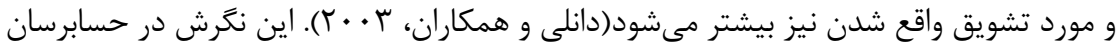

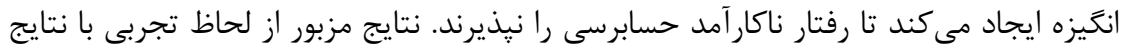

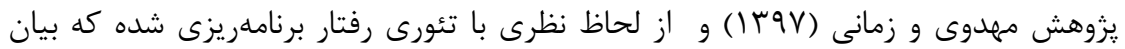

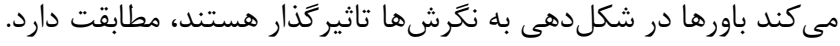

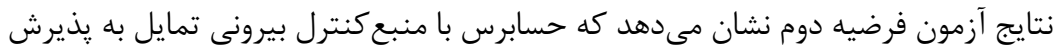

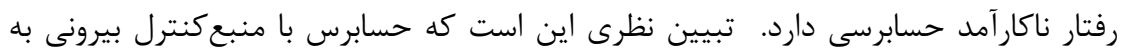

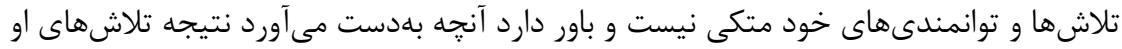

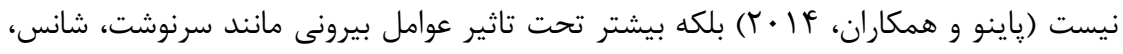

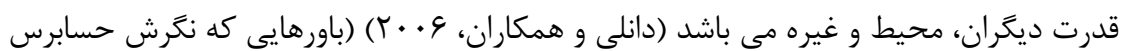


نسبت به رفتار را شكل مىدهند). اينكونه حسابرسان اطمينان دارند كه محيط از آنها انتظار دارد

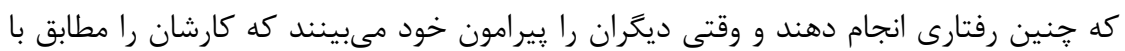

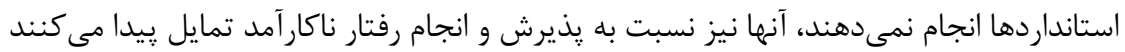

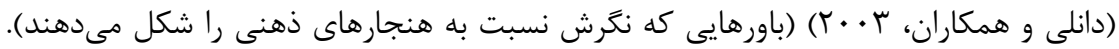

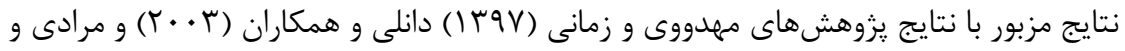

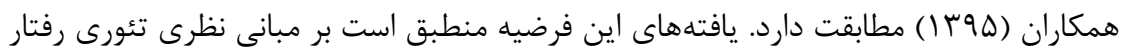

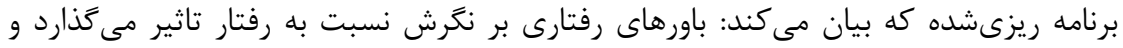

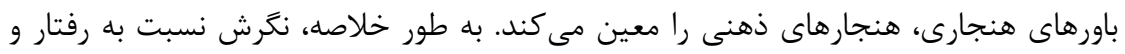

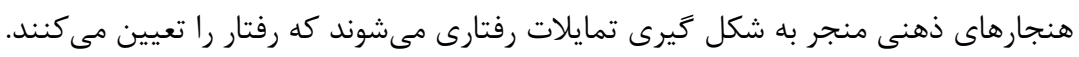

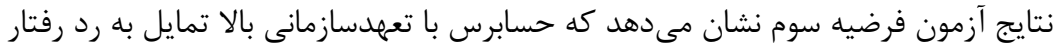

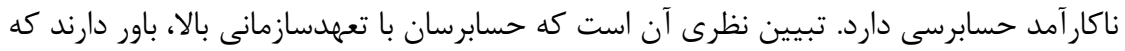

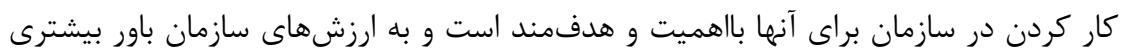

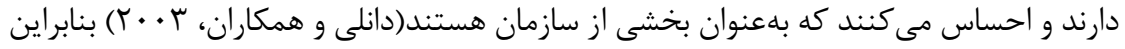

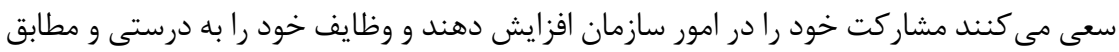

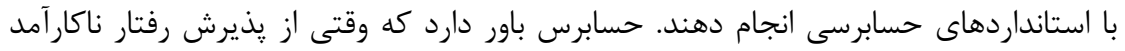

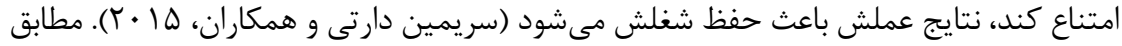
با تئورى تعهدسازمانى، حسابرسان متعهد به سازمان باورهاى قوى درباره اهداف سازمان دارند

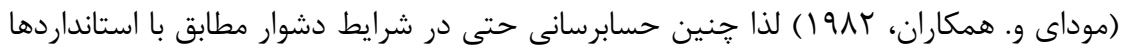

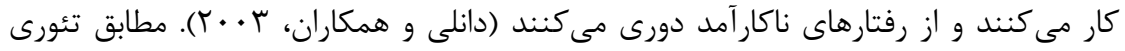

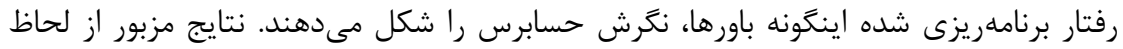

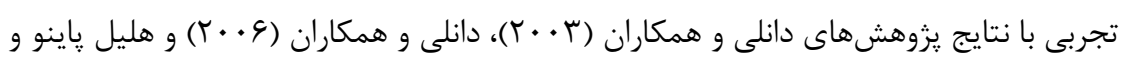

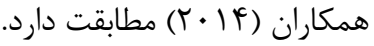
با توجه به نتايج فوق موسسههاى حسابرسى بايد بهاين نكته توجه كنند كه در استخدام

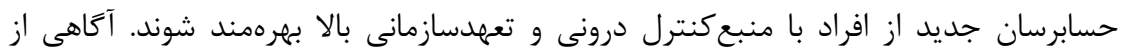

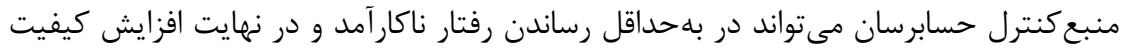
حسابرسى مفيد باشد. بنابر اين بيشنهاد مى شود موسسههاى حسابرسى برنامه نهاى توسعه حرفهاى

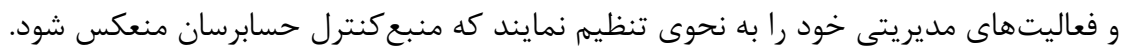

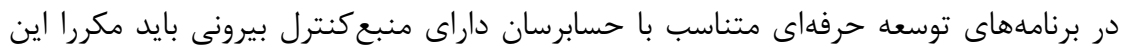

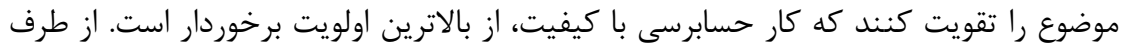

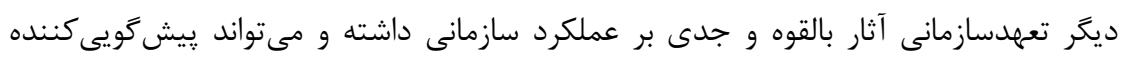




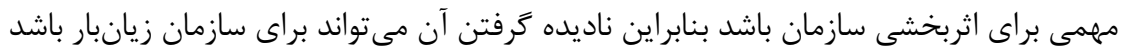

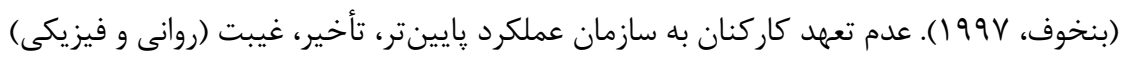

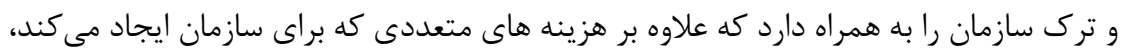

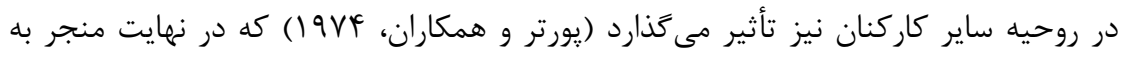

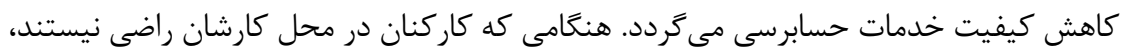

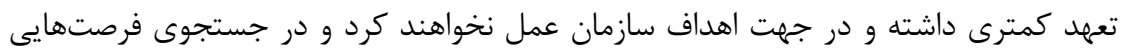

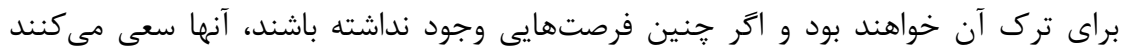

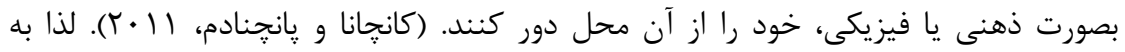

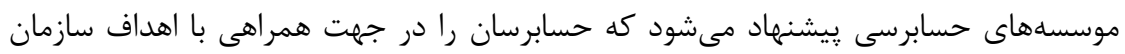

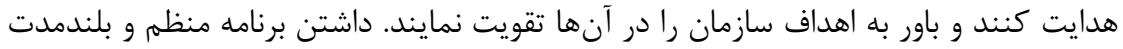

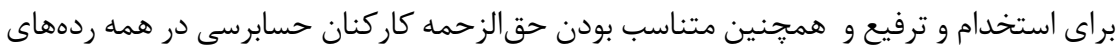

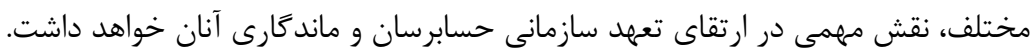

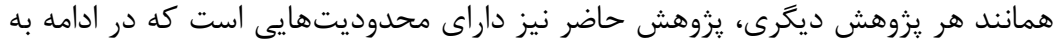

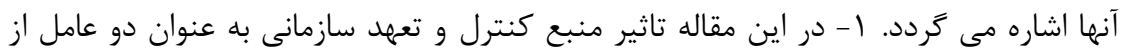

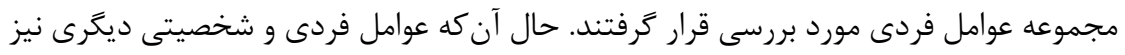

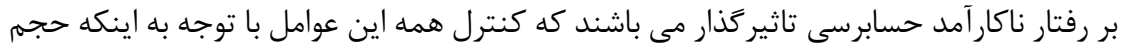

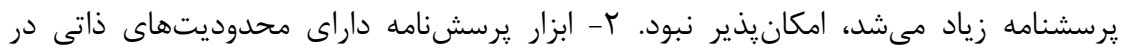

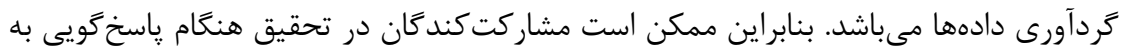
سوالات يرسشنامه دقت كافى نداشته باشند.

\section{V- - Vقدير، تشكر و ملاحظات اخلاقى}

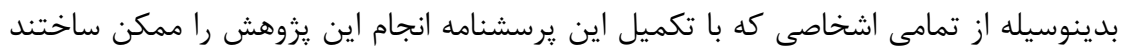
نهايت قدردانى و سياس را داريم.

\section{קֶيوست: يرسشنامه \\ حسابرس كرامى}

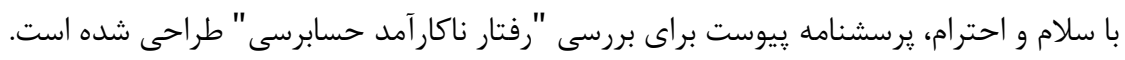

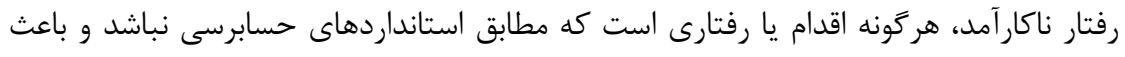

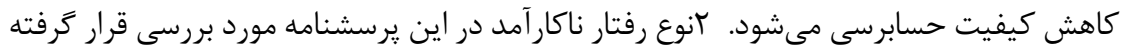

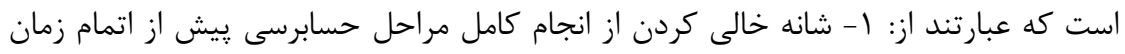


فرايند حسابرسى : شانه خالى كردن زمانى رخ مىدهد كه يك حسابرس مر احل لازم براى انجام

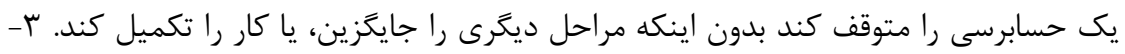

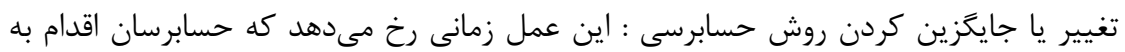

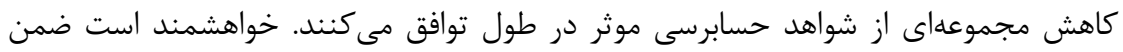

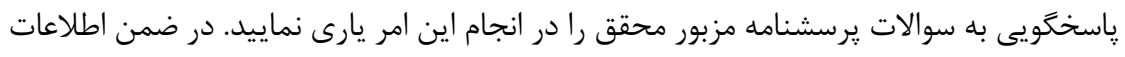

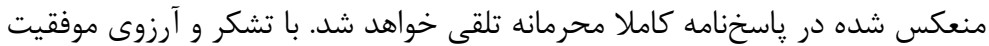
بخش الف: يرسش إنهاى عمومى:

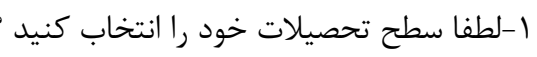
دكترى r- در حال حاضر موقعيت شغلى شما جيست؟ مدير سريرست ارشده سريرسته حسابرس ارشده آناصن

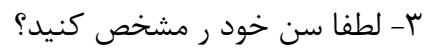
بيش از Q أ سال

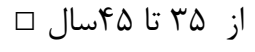
كمتر از هـ ساله

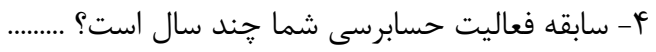
بخش ب: يرسش هاى تخصصى:

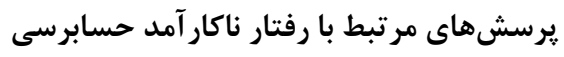

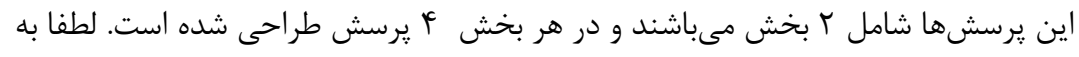

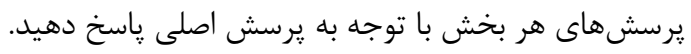

\begin{tabular}{|c|c|c|c|c|c|c|c|}
\hline & ن اكر & س & يُذ & ر قابر & i & برس & شانه خالى كردن از انجام كامل مراحل حسابرسى توسط حس \\
\hline $\begin{array}{l}\frac{5}{3} \\
\frac{3}{2} \\
\frac{9}{2}\end{array}$ & $\frac{2}{: 2}$ & $\begin{array}{l}3 \\
3 \\
\frac{3}{2} \\
: \frac{2}{2}\end{array}$ & 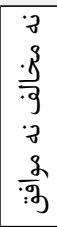 & $\begin{array}{l}3.3 \\
3 \\
.3 \\
.3 \\
.3\end{array}$ & $\frac{\beta}{3}$ & $\begin{array}{l}\frac{5}{3} \\
\lambda \\
.9 \\
.9\end{array}$ & \\
\hline & & & & & & & | أحسابرسان بر اين باور باشند كه اكر مراحل حسابرسى \\
\hline & & & & & & & به وج درد حسابرسى هاى قبلى مشكلى در اسناد/سيستم مشترى \\
\hline & & & & & & & 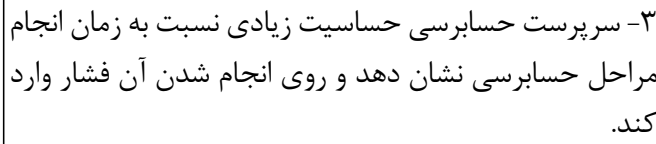 \\
\hline
\end{tabular}




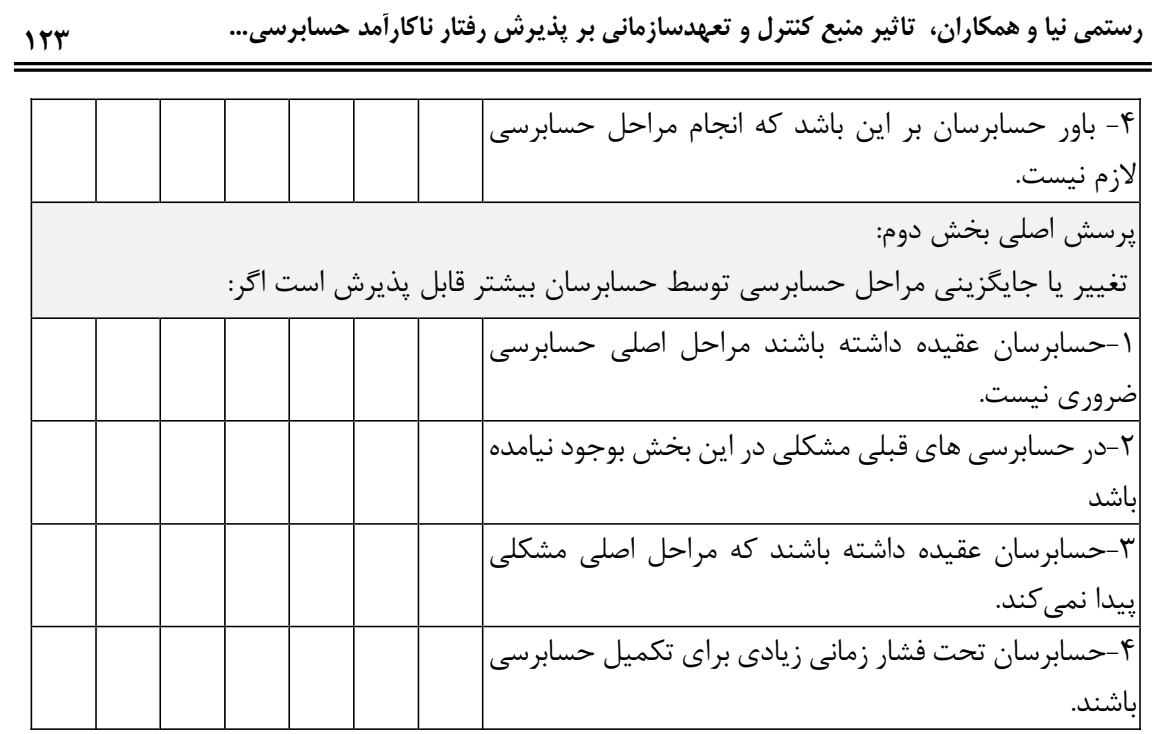

يرسشهاى مرتبط با منبع كنترل بيرونى

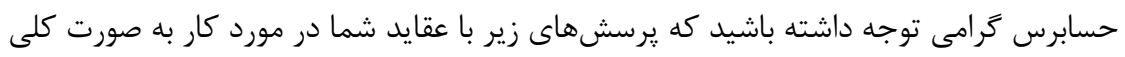

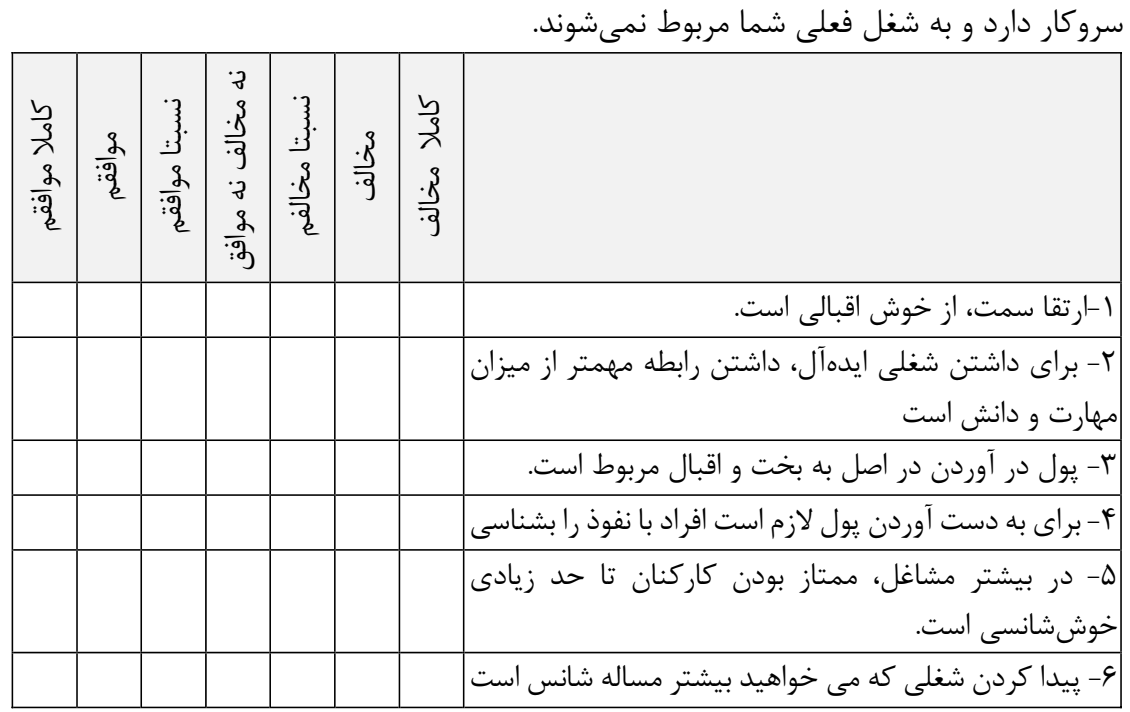
كزارههاى مرتبط با منبع كنترل درونى

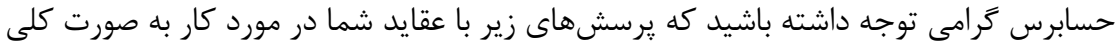

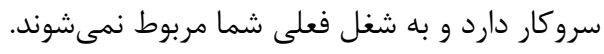


دو فصلنامه حسابدارى ارزشى و رفتارى، سال ينجم، شماره دهم، پِإييز و زمستان وجسا

\begin{tabular}{|c|c|c|c|c|c|c|c|}
\hline $\begin{array}{l}b \\
\frac{3}{\lambda} \\
\frac{g}{2} \\
\vdots 2\end{array}$ & $\frac{2}{3}$ & $\begin{array}{l}3 \\
\frac{3}{3} \\
\frac{3}{3} \\
3\end{array}$ & $\begin{array}{l}\cdot 7 \\
. \beta \\
.3 \\
.3 \\
.7 \\
\frac{3}{9}\end{array}$ & 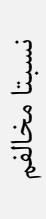 & .9 & 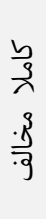 & \\
\hline & & & & & & & 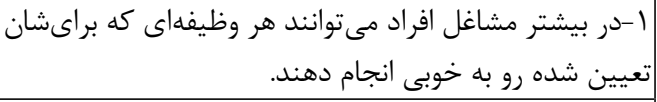 \\
\hline & & & & & & & 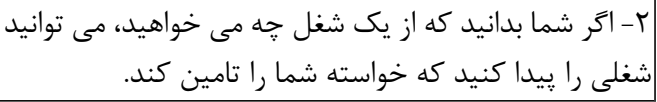 \\
\hline & & & & & & & شده ناراضى هستر كاركنان از تصميمى كه به وسيله كارى در اين باره انجام دهند شان اتخاذ. \\
\hline & & & & & & & |انجام دهند. بيشتر افراد اكر تلاش كنند، مى توانند كارشان را به خوبى \\
\hline & & & & & & & مه دهند ارتقا به افرادى داده مى شود كه كارشان را به خوبى انجام \\
\hline & & & & & & & ياداش دريافت مى به كنند. كلى افرادى كه كارشان را خوب انجام مى دهند، \\
\hline
\end{tabular}

كزارههاى مرتبط با تعهدد سازمانى

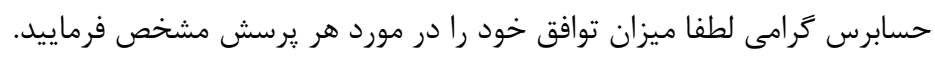

\begin{tabular}{|c|c|c|c|c|c|c|c|}
\hline $\begin{array}{l}\frac{b}{3} \\
\frac{3}{2} \\
\frac{\alpha}{9}\end{array}$ & $\frac{g}{9}$ & $\begin{array}{l}3 \\
\frac{3}{3} \\
39 \\
3\end{array}$ & $\begin{array}{l}.3 \\
.3 \\
.3 \\
.3 \\
\frac{3}{9} \\
\frac{9}{9}\end{array}$ & 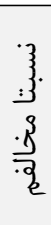 & .93 & $\begin{array}{l}5 \\
3 \\
\lambda \\
.3 \\
.3\end{array}$ & \\
\hline & & & & & & & 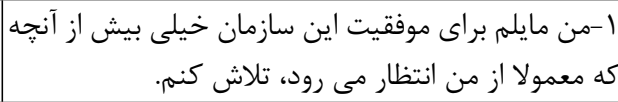 \\
\hline & & & & & & & 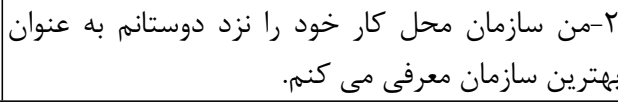 \\
\hline & & & & & & & بـ بـ من محواى ادامه كار در اين سازمان، هر نوع وظيفه اى را كه \\
\hline & & & & & & & به هم شبيه هستند. هاى من و ارزش هاى سازمان محل كارم خيلى \\
\hline & & & & & & & هـ-من افتخار مى كنم كه به ديكران بكويم كه عضوى از \\
\hline
\end{tabular}




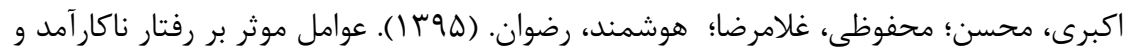

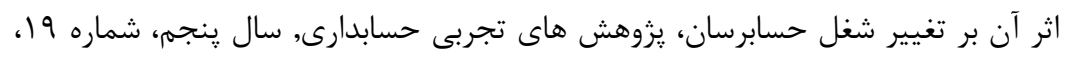

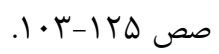

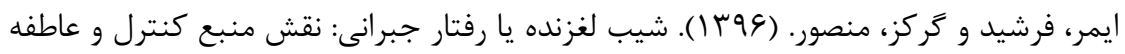

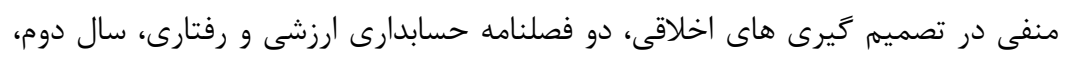
شماره جهارم، صص در تصنيم

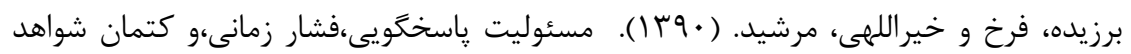

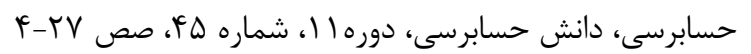

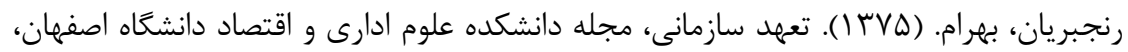

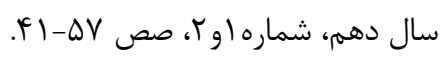

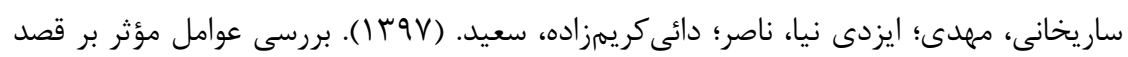

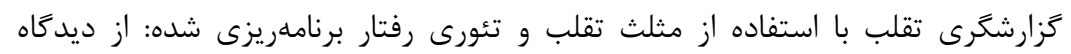

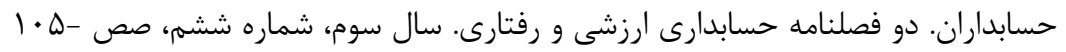

$.17 \mathrm{~m}$

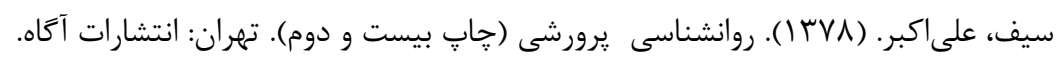

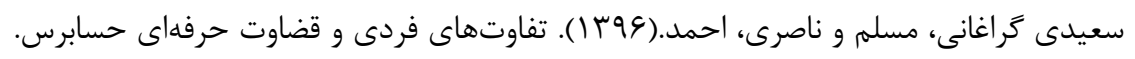

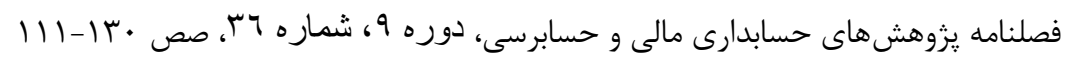

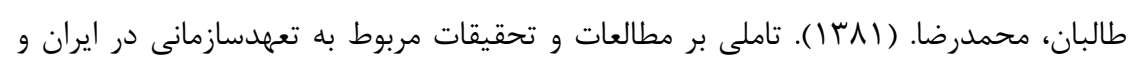

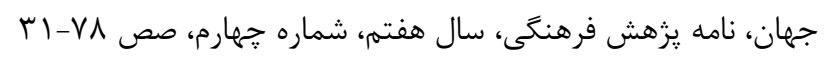

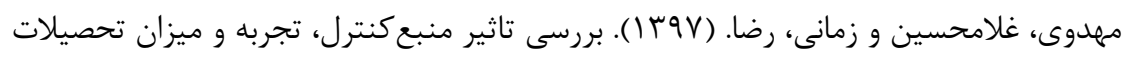

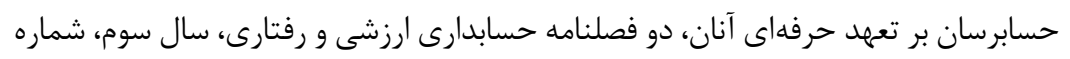

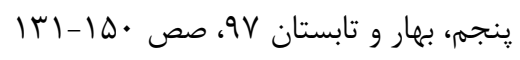




$$
\begin{aligned}
& \text { دو فصلنامه حسابدارى ارزشى و رفتارى، سال ينجم، شماره دهم، پإييز و زمستان 99"1 } \\
& \text { لارى دشت بياض، محمود؛ صالحى، مهدى؛ زاهدى، مرضيه.(99 ()). بررسى رفتار ناكارآمد } \\
& \text { حسابرسان و روابط كارى با سريرستان، نقش تعديلى جو اخلاقى مديران، دو فصلنامئه }
\end{aligned}
$$

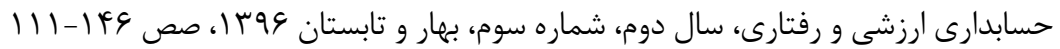

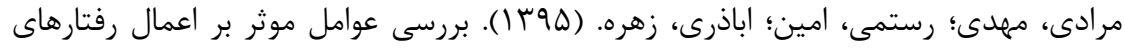

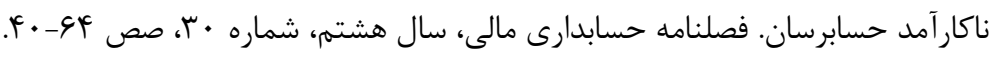

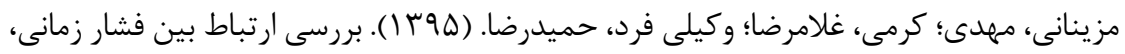

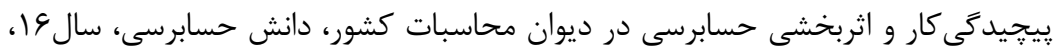

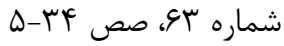

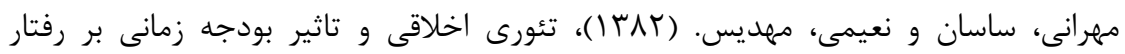

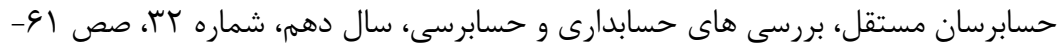

$$
\begin{aligned}
& \text {. } 4 \text { r } \\
& \text { هادى اده مقدم، اكرم؛ رضاييان، على؛ طبرسا، غلامعلى؛ رامينمهر، حميد. (بوجا). ارائه مدل }
\end{aligned}
$$

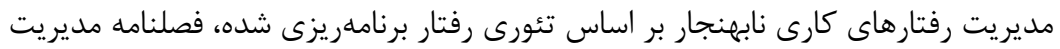

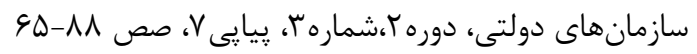

Ajzen, I., and Fishbein, M. 2003. Questions Raised by a Reasoned Action Approach: Reply to Ogden. Health Psychology 23: 431-438

Ajzen, I., and Fishbein, M. 2000. Attitudes and the Attitude-Behavior Relation: Reasoned and Automatic Processes. In W. Stroebe \& M. Hewstone (Eds.). European Review of Social Psychology 11: 1-33.

Alderman, C. W., and Deitrick, J. W. 1982. Auditors' Perception of Time Budget Pressures and Premature Sign offs: A Replication and Extension. Auditing: A Journal of Practice \& Theory 1(2):54-68.

Baskara, A. E., and Ike, S. 2011. Penerimaan Auditor atas Dysfunctional Audit Behavior (Studi Empiris Pada Kantor Akuntan Publik di Jawa Tengah). MAKSI 11(1): 1-17.

Benkhoff, B. 19970. Ignoring Commitment Is Costly: New Approaches to Establish the Missing Link between Commitment and Performance. Human Relations 26: 701-726.

Chan, K., Kleinman, G., and Lee, P. 2009. The Impact of Sarbanes-Oxley on Internal Control Remediation. International Journal of Accounting \& Information Management 17(1): 53-65.

Kanchana, P., and Panchanatham N. 2012. Analytical study on Organizational Commitment with Reference to Tamil Nadu Papers limited, Kagidapuram, Karur District. International Journal of Multidisciplinary Research, 2(1). 
رستمى نيا و همكاران، تاثير منبع كنترل و تعهدسازمانى بر بذيرش رفتار ناكار آمد حسابرسى...

Desmond C.Y. Yuen., Philip K.F. Law., and Chan Lu, Jie Qi Guan, 2013 Dysfunctional auditing behaviour: empirical evidence on auditors' behaviour in Macau. International Journal of Accounting \& Information Management, 21 (3): 209-226,

Donnelly, D. P., and Quirin, J. J., and Bryan, D. O. 2003. Auditor Acceptance of Dysfunctional Audit Behavior: An Explanatory Model Using Auditors Personal Characteristics. Behavioral Research in Accounting 15: 87-110.

Donnelly, D. P., and Quirin, J. J., and Bryan, D. O. 2006. Attitudes toward Dysfunctional Audit Behavior: The Effects of Locus of Control, Organizational Commitment, and Position. The Journal of Applied Business Research 19(1): 95-108 .

Donnelly, D. P., and Quirin, J. J., and Bryan, D. O. 2011. Attitudes toward Dysfunctional Audit Behavior: The effects of Locus of Control, Organizational Commitment, and Position. Journal of Applied Business Research (JABR) 19(1).

Frucot, V., and Shearon, W. T. 1991. Budgetary Participation, Locus of Control, and Mexican Managerial Performance and Job Satisfaction. The Accounting Review 66(1): 80-99 .

Gable, M., and F. Dangello. 1994. Locus of control, Machiavellianism, and managerial job performance. The Journal of Psychology 128: 599608.

Ghorbanpour, Z., and Dehnavi, H. D., and Heyrani, F. 2014. Examination of Auditor Acceptance of Dysfunctional Behavior Using a Heuristic Model. International Journal of Academic Research in Accounting, Finance and Management Sciences 4(1): 41-51.

Hyatt, T. A., and Prawitt, D. F. 2001. Does Congruence Between Audit Structure and Auditors' Locus of Control Affect Job Performance. The Accounting Review 76(2): 263-274 .

Koonce, L.L., and Mercer, M. (2005). Using Psychology Theories in Archival Financial Accounting Research. McCombs Research Paper Series No. ACC-01-05.

Lightner, S. M., and Adams, S. J., and Lightner, K. M. 1982. The influence of Situational, Ethical, and Expectancy Theory Variables on Accountants' Underreporting Behavior. Auditing: A Journal of Practice \& Theory 2: 1-12 .

Malone, C. F., and Roberts, R. W. 1996. Factors Associated with the Incidence of Reduced Audit Quality Behaviors. Auditing: A Journal of Practice and Theory 15(2).

Margheim, L., and Kelley, T. 1990. The Impact of Time Budget Pressure Personality, and Leadership Variables on Dysfunctional Auditor Behavior. Auditing: A Journal of Practices \& Theory 9: 21-42 . 
Margheim, L., and Pany, K. 1986. Quality Control, Premature Signoff, and Underreporting of Time: Some Empirical Findings. Auditing: A Journal of Practice \& Theory 5(2): 50-63.

Mowday, R., Porter, L. W., and Steers R. M. 1982. Employee-Organizational Linkages. New York, NY: Academic Press.

Mowday, R., Steers, R. M., and Porter, L. W. 1979. The measurement of Organizational Commitment. Journal of Vocational Behavior 14: 224-227.

Paino, H., Ismail, Z., and Smith, M .2014 .Modelling Dysfunctional Behaviour: Individual Factors and Ethical Financial Decision. Procedia - Social and Behavioral Sciences 145: 116-128 .

Paino, H., Pahang, U. T. M., and Ismail, Z., Smith, M. 2011. Dysfunctional Audit Behaviour: The Effects of Employee Performance, Turnover Intentions and Locus of Control. Journal of Modern Accounting and Auditing 7(4): 418-423.

Porter, L.W., Steers, R.M., and Mowday, R.T., and Boulian, P.V. 1974, Organizational Commitment, Job Satisfaction, and Turnover among Psychiatric Technicians. Journal of Applied Psychology 59: 603-609

Rotter, J. B. 1973. The Future of Clinical Psychology. Journal of Consulting and Clinical Psychology 40(2): 313-321 .

Shapeero, M., Chye Koh, H., and Killough, L. N. 2003. Underreporting and Premature Sign-off in Public Accounting. Managerial Auditing Journal 18(6/7): 478-489.

Spalding, M. D., and Grenfell, A. M. 1997. New estimates of Global and Regional Coral Reef Areas. Coral Reefs 16(4): 225-230.

Solar, D., and D. Bruehl. 1971. Machiavellianisn and locus of control: Two conceptions of interpersonal power. Psychological Reports 29: 10791082.

Spector, P. E. 1988. Development of the Work Locus of Control Sscale. Journal of Occupational Psychology 61: 335-340.

Spector, P. E. 1982. Behavior in organizations as a function of employee's locus of control. Psychological Bulletin 91: 482-497.

Sulistiyo, H., \& Ghozali, I. (2017). The Role of Religious Control in Dysfunctional Audit Behavior: An Empirical Study of Auditors of Public Accounting Firm in Indonesia. Journal of Applied Business Research (JABR), 33(5), 1047-1058.

Sulistiyo, H., Darsono, D., and Subchan, S. 2018. An empirical study on the role of auditor independence in reducing dysfunctional audit behavior of public accountants in Indonesia. Quality - Access to Success. 19(167):93-97.

Srimindarti, C., and Widati, L. W. 2015. The Effect of Locus of Control and Organizational Commitment to Acceptance of Dysfunctional Audit 
1 rq رستمى نيا و همكاران، تاثير منبع كنترل و تعهدسازمانى بر يذيرش رفتار ناكارآمد حسابرسى...

Behavior Based on the Theory of Planned Behavior. International Journal of Business, Economics and Law 7(1): 27-35.

Svanstrom. T. 2016. Time Pressure, Training Activities and Dysfunctional Auditor Behaviour: Evidence from Small Audit Firms. International Journal of Auditing. 20: 42-51

Tervo, T., Murphy, L, S., and Pitman, M. 2014. Dysfunctional Auditor Behavior: The Effects of Tone at the Top and Supervisors' Relationships, in (ed.) Research on Professional Responsibility and Ethics in Accounting (Research on Professional Responsibility and Ethics in Accounting, 17: 47 - 77 